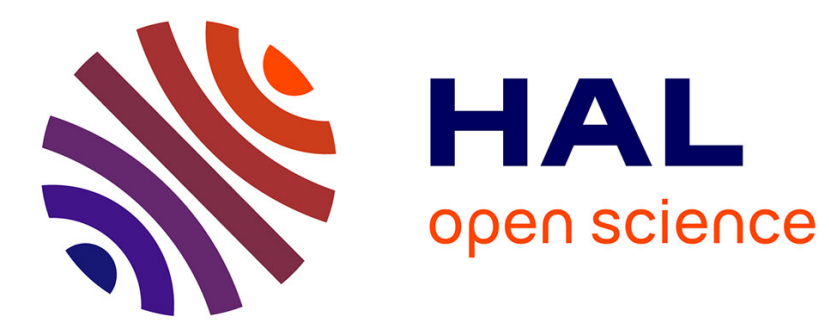

\title{
Synthesis and Reactivity of Low-Valent Group 14 Element Compounds
}

Manfred Scheer, Brian Johnson, Stefan Almstätter, Fabian Dielmann, Michael Bodensteiner

\section{- To cite this version:}

Manfred Scheer, Brian Johnson, Stefan Almstätter, Fabian Dielmann, Michael Bodensteiner. Synthesis and Reactivity of Low-Valent Group 14 Element Compounds. Journal of Inorganic and General Chemistry / Zeitschrift für anorganische und allgemeine Chemie, 2010, 636 (7), pp.1275. 10.1002/zaac.201000029 . hal-00552445

\section{HAL Id: hal-00552445 https://hal.science/hal-00552445}

Submitted on 6 Jan 2011

HAL is a multi-disciplinary open access archive for the deposit and dissemination of scientific research documents, whether they are published or not. The documents may come from teaching and research institutions in France or abroad, or from public or private research centers.
L'archive ouverte pluridisciplinaire HAL, est destinée au dépôt et à la diffusion de documents scientifiques de niveau recherche, publiés ou non, émanant des établissements d'enseignement et de recherche français ou étrangers, des laboratoires publics ou privés. 


\section{Zeitschrift für Anorganische und}

Allgemeine Chemie

\section{Synthesis and Reactivity of Low-Valent Group 14 Element Compounds}

\begin{tabular}{|r|l|}
\hline Journal: & Zeitschrift für Anorganische und Allgemeine Chemie \\
\hline Manuscript ID: & zaac. 201000029.R2 \\
\hline Wiley - Manuscript type: & Article \\
\hline Date Submitter: & 01-Apr-2010 \\
\hline Complete List of Authors: & $\begin{array}{l}\text { Scheer, Manfred; Universitaet Regensburg, Institut für } \\
\text { Anorganische Chemie } \\
\text { Johnson, Brian } \\
\text { Almstätter, Stefan } \\
\text { Dielmann, Fabian } \\
\text { Bodensteiner, Michael }\end{array}$ \\
\hline Keywords: & tin, germanium, phosphorus \\
\hline & \\
\hline $\begin{array}{l}\text { Note: The following files were submitted by the author for peer review, but cannot be converted } \\
\text { to PDF. You must view these files (e.g. movies) online. }\end{array}$ \\
\hline $\begin{array}{l}\text { scheme1.cdx } \\
\text { scheme2.cdx } \\
\text { scheme3.cdx } \\
\text { equations.cdx }\end{array}$ \\
\hline
\end{tabular}

\section{scholaroNE" \\ Manuscript Central}




\title{
Synthesis and Reactivity of Low-Valent Group 14 Element
}

Compounds

\author{
Brian P. Johnson, Stefan Almstätter, Fabian Dielmann, Michael \\ Bodensteiner, and Manfred Scheer*
}

\author{
Regensburg, Institut für Anorganische Chemie der Universität \\ Received: \\ Dedicated to Professor Gerd Becker on the occasion of his $70^{\text {th }}$ birthday
}

Keywords: Germanium / Tin / Phosphorus / Multiple bonding / DFT calculations

Abstract: The tetravalent germanium and tin compounds of the general formulae $\mathrm{Ph}^{*} \mathrm{EX}_{3}$ $\left(\mathrm{Ph}^{*}=2,6-\right.$ Trip $_{2}-\mathrm{C}_{6} \mathrm{H}_{3}$, Trip $=\mathrm{C}_{6} \mathrm{H}_{2} i \mathrm{Pr}_{3}-2,4,6 ; \mathrm{E}=\mathrm{Sn}, \mathrm{X}=\mathrm{Cl}(\mathbf{1 a}), \mathrm{Br}(\mathbf{1 b}) ; \mathrm{E}=\mathrm{Ge}, \mathrm{X}=\mathrm{Cl}$ (2)) are synthesised by reaction of $\mathrm{Ph}^{*} \mathrm{Li}^{-} \mathrm{OEt}_{2}$ with $\mathrm{EX}_{4}$. The subsequent reaction of 1a,b with $\mathrm{LiP}\left(\mathrm{SiMe}_{3}\right)_{2}$ leads to $\mathrm{Ph} * \mathrm{EP}\left(\mathrm{SiMe}_{3}\right)_{2}(\mathrm{E}=\mathrm{Sn}(3), \mathrm{Ge}$ (4)) and the diphosphine $\left(\mathrm{Me}_{3} \mathrm{Si}\right)_{2} \mathrm{PP}\left(\mathrm{SiMe}_{3}\right)_{2}$ via a redox reaction. In an alternative approach $\mathbf{3}$ and $\mathbf{4}$ are synthesised by using the corresponding divalent compounds $\mathrm{Ph} * \mathrm{ECl}(\mathrm{E}=\mathrm{Ge}, \mathrm{Sn})$ in the reaction with $\mathrm{LiP}\left(\mathrm{SiMe}_{3}\right)_{2}$. The reactivity of $\mathrm{Ph} * \mathrm{SnCl}$ is extensively investigated to give with $\mathrm{LiP}(\mathrm{H})$ Trip a tin(II)-phosphine derivative $\mathrm{Ph} * \mathrm{SnP}(\mathrm{H})$ Trip (6) and with $\mathrm{Li}_{2}$ PTrip a proposed product $\left[\mathrm{Ph}^{*} \text { SnPTrip }\right]^{-}$(7) with multiple bonding between tin and phosphorus. The latter feature is confirmed by DFT calculations on a model compound $[\mathrm{PhSnPPh}]^{-}$. The reaction with $\mathrm{Li}\left[\mathrm{H}_{2} \mathrm{PW}(\mathrm{CO})_{5}\right]$ gives the oxo-bridged tin compound $\left[\mathrm{Ph} * \mathrm{Sn}\left\{\mathrm{W}(\mathrm{CO})_{5}\right\}(\mu-\mathrm{O})_{2} \mathrm{SnPh}^{*}\right](8)$ as the only isolable product. However, the existence of $\mathbf{8}$ as the bis-hydroxo derivative $\left[\mathrm{Ph} * \mathrm{Sn}\left\{\mathrm{W}(\mathrm{CO})_{5}\right\}(\mu-\mathrm{OH})_{2} \mathrm{SnPh}^{*}\right] \quad(\mathbf{8 a})$ is also possible. The $\mathrm{Sn}(\mathrm{IV})$ derivatives $\mathrm{Ph}^{*} \mathrm{Sn}\left(\mathrm{OSiMe}_{3}\right)_{2} \mathrm{Cl}(\mathbf{9})$ and $\left[\mathrm{Ph} * \mathrm{Sn}(\mu-\mathrm{O}) \mathrm{Cl}_{2}(\mathbf{1 0})\right.$ are obtained by the oxidation of $\mathrm{Ph} * \mathrm{SnCl}$ with bis(trimethylsilyl)peroxide and with $\mathrm{Me}_{3} \mathrm{NO}$, respectively. Besides the spectroscopic characterisation of the isolated products compounds $1 \mathrm{a}, \mathbf{2}, \mathbf{3}, \mathbf{4}, \mathbf{8}$, and $\mathbf{1 0}$ are additionally characterised by X-ray diffraction analysis.

* Prof. Dr. M. Scheer

Institut für Anorganische Chemie der Universität Regensburg,

D-93040 Regensburg (Germany)

Fax: (+49) 941/943-4441

E-mail: manfred.scheer@chemie.uni-regensburg.de 


\section{Introduction}

Almost 3 decades ago G. Becker et al. succeeded in the synthesis of the first stable phosphaalkyne, tert-butylphosphaalkyne, ${ }^{[1]}$ which through an improved synthesis ${ }^{[2]}$ gave a general approach to this class of $\mathrm{P} \equiv \mathrm{C}$ triply bound compounds on a preparative scale, and many representatives have since appeared. ${ }^{[3]}$ In contrast, arsaalkynes are extremely rare, with the first stable compounds, Mes* $\mathrm{C} \equiv \mathrm{As}$, reported in $1986 .{ }^{[4]}$ A recent development was reported by the synthesis of the borate derivatives $\left[\left(\mathrm{F}_{3} \mathrm{C}\right)_{3} \mathrm{BC} \equiv \mathrm{P}\right]^{-}$and $\left[\left(\mathrm{F}_{3} \mathrm{C}\right)_{3} \mathrm{BC} \equiv \mathrm{As}\right]^{-}$ representing phosphaethynyl and arsaethynyl systems. ${ }^{[5]}$ The reaction behaviour of phosphaalkynes was intensively investigated both for phosphaorganic ${ }^{[6]}$ and coordination chemistry $^{[7]}$ purposes. Moreover, the discovery of G. Becker opened up the research field of multiple bonding of the heavier main-group elements. ${ }^{[8]}$ Compounds of the type $\mathrm{R}_{2} \mathrm{E}=\mathrm{PR}$ ' with heavier group 14 elements were isolated possessing $\mathrm{Si}=\mathrm{P},{ }^{[9]} \mathrm{Ge}=\mathrm{P},{ }^{[10]}$ and $\mathrm{Sn}=\mathrm{P}^{[11]}$ double bonds, which were stabilised kinetically by bulky aryl groups (Mes $\left(\mathrm{C}_{6} \mathrm{H}_{2} \mathrm{Me}_{3}-2,3,6\right)$; Trip $\left(\mathrm{C}_{6} \mathrm{H}_{2} i \mathrm{Pr}_{3}-2,3,6\right)$; Mes* $\left.\left(\mathrm{C}_{6} \mathrm{H}_{2} t \mathrm{Bu}_{3}-2,3,6\right)\right)$; or by bulky aliphatic groups $(t \mathrm{Bu}$ or $\left.\mathrm{CH}\left(\mathrm{SiMe}_{3}\right)_{2}\right)$ at both phosphorus and the group 14 element atom. Additionally, $P$-silyl and $P$ phosphanyl derivatives were successfully prepared in compounds of type $\mathrm{R}_{2} \mathrm{Si}=\mathrm{PSiR}_{3}$ and $\mathrm{R}_{2} \mathrm{Si}=\mathrm{PPR}{ }_{2 \cdot}{ }^{[12]}$ A novel chapter of multiple-bond chemistry was opened, when the so-called 'terphenyl' substituent was introduced in main group chemistry. Thus, a novel stannaacetylene, $\mathrm{Ph} * \mathrm{Sn} \equiv \mathrm{CSi} i \mathrm{Pr}_{3}\left(\mathrm{Ph}^{*}=\mathrm{C}_{6} \mathrm{H}_{3} \operatorname{Trip}_{2}-2,6\right)$, was proposed to exist as a reactive intermediate, ${ }^{[13]}$ and the asymmetric dipnictenes $\mathrm{Ph} * \mathrm{E}=\mathrm{PMes}(\mathrm{E}=\mathrm{As}, \mathrm{Sb})$ were synthesized by the Power group. ${ }^{[14]}$ Moreover, novel arsa-Wittig reagents 2,6-Ph' ${ }_{2}-\mathrm{C}_{6} \mathrm{H}_{3} \mathrm{As}=\mathrm{PMe}_{3}(\mathrm{Ph}$ ' = Mes, Trip) were developed by Protasiewicz and co-workers, whereby the phosphorus atom is in the +5 oxidation state. ${ }^{[15]}$

Our long-term engagement in phosphaalkyne chemistry ${ }^{[16]}$ presents the question of whether group 14 elements other than carbon can be used for the synthesis of compounds with a triple bond to phosphorus. Compounds featuring a $\mathrm{E} \equiv \mathrm{P}(\mathrm{E}=\mathrm{Si}, \mathrm{Ge}, \mathrm{Sn}, \mathrm{Pb})$ triple bond have not yet been detected or isolated. Only a compound with a $\mathrm{Si}=\mathrm{P}$ triple bond is tentatively proposed as an unobserved intermediate, the identity of which is suggested based solely on the nature of the isolated product (Scheme 1). ${ }^{[17]}$ Matrix isolation studies show the access to $\mathrm{H}_{3} \mathrm{SiP}$ and its isomers. ${ }^{[18]}$ Moreover, a phosphasilene, $\mathrm{RR}^{\prime} \mathrm{Si}=\mathrm{PH}\left(\mathrm{R}=\mathrm{Ph}^{*}, \mathrm{R}^{\prime}=t \mathrm{Bu}_{3} \mathrm{Si}\right)$, and its Zinc salt were synthesised in the Driess group ${ }^{[19]}$ and $\mathrm{Cp} *(\mathrm{Cl})_{2} \mathrm{EP}\left(\mathrm{SnMe}_{3}\right)_{2}(\mathrm{E}=\mathrm{Si}, \mathrm{Ge})$ was synthesised by Niecke and Pietschnig. ${ }^{[20]}$ All these compounds are on the way to realising stable derivatives with an $\mathrm{E} \equiv \mathrm{P}$ triple bond. Interestingly, the stability of triply bonded $\mathrm{RSn} \equiv \mathrm{P}$ 
systems has been predicted by quantum chemical calculations only for examples in which $\mathrm{R}$ represents a bulky terphenyl group. ${ }^{[21]}$
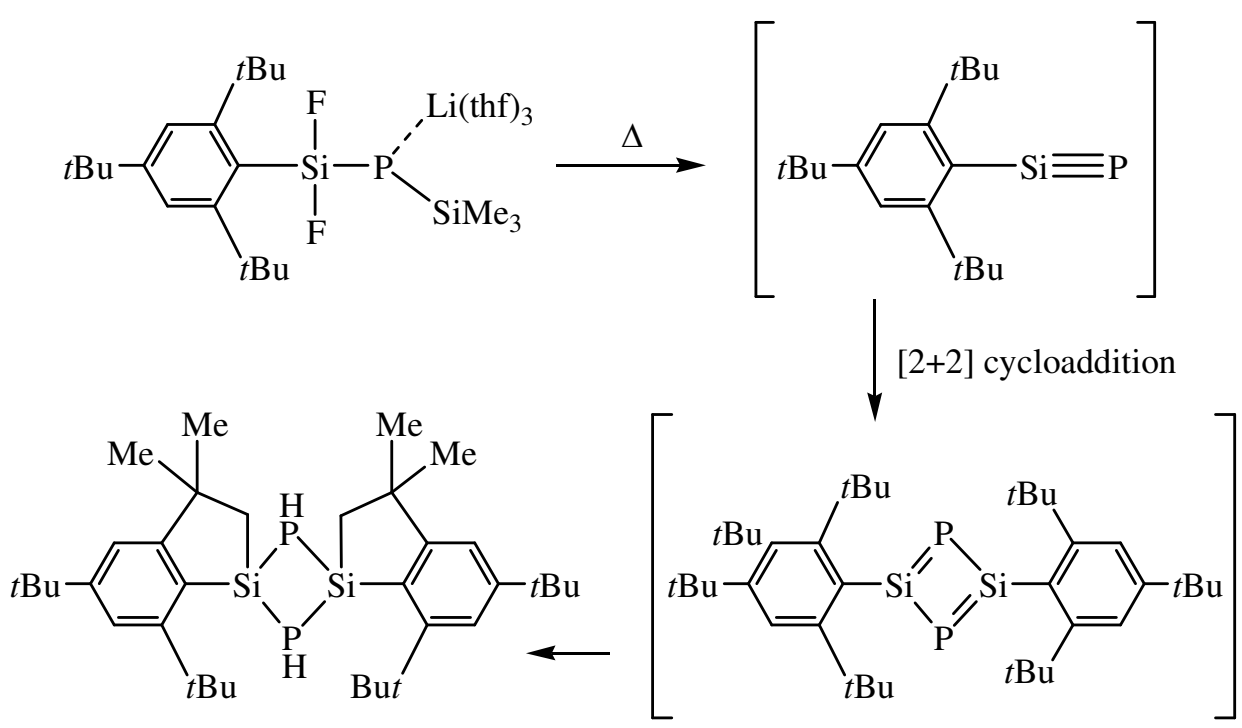

Scheme 1. Reaction pathway of thermolysis of $\mathrm{Mes} * \mathrm{Si}(\mathrm{F})_{2} \mathrm{P}\left\{\mathrm{Li}(\mathrm{thf})_{3}\right\} \mathrm{SiMe}_{3}$ and proposed generation of intermediate $\mathrm{Mes} * \mathrm{Si} \equiv \mathrm{P}{ }^{[17]}$

Thus, the use of bulky terphenyl substituents like, e.g., $\mathrm{Ph}^{*}\left(\mathrm{Ph}^{*}=\mathrm{C}_{6} \mathrm{H}_{3}\right.$ Trip 2 -2,6; Trip = $\mathrm{C}_{6} \mathrm{H}_{2} i \mathrm{Pr}_{3}-2,4,6$ ) on tin or germanium (E) provides a unique heteroleptic template for preparing element-phosphorus compounds with low-coordination geometries. With the relatively stable $\mathrm{E}-\mathrm{C}_{\mathrm{aryl}}$ bond anchoring the group 14 atom at one site, reactivity with phosphorus compounds is probed at the remaining coordination sites. As a result, a heteroleptic terphenyl-tin or germanium phosphanide would represent an optimal precursor for the synthesis of $\mathrm{E} \equiv \mathrm{P}$ triplebond compounds of the type $\mathrm{Ph} * \mathrm{E} \equiv \mathrm{P}(\mathrm{E}=\mathrm{Sn}, \mathrm{Ge})$. The experiments reported in the following are partly directed toward this goal. Moreover, the results described give insight into the reaction behaviour of low-valent tin compounds.

\section{Results and Discussion}

Synthesis of terphenyl-trihalogeno-germanium(IV)- and tin(IV) compounds: The most direct preparation of compounds of the formulae $\mathrm{Ph}^{*} \mathrm{EX}_{3}\left(\mathrm{Ph}^{*}=2,6-\mathrm{Trip}_{2}-\mathrm{C}_{6} \mathrm{H}_{3}\right.$, Trip $=$ $\left.\mathrm{C}_{6} \mathrm{H}_{2} i \mathrm{Pr}_{3}-2,4,6\right)$ is achieved by treating $\mathrm{Ph} * \mathrm{Li}^{-} \mathrm{OEt}_{2}$ with $\mathrm{EX}_{4}$ in a mixture of $n$-hexane and $\mathrm{Et}_{2} \mathrm{O}$ (Eq. 1). Colorless crystals of the products are obtained after work-up and recrystallization from $n$-hexane in moderate yields of 37-45\%. The oxidation of $\mathrm{Ph} * \mathrm{SnCl}(3)$ by $\mathrm{PCl}_{3}$ gives a higher yield of $\mathbf{1 a}(68 \%)$. However, the current transmetalation method saves 
the step of preparing $\mathrm{Ph} * \mathrm{SnCl}$ and allows the synthesis of $\mathbf{1 a}$ in a larger scale. Saito et al. obtained a yield of $45 \%$ by oxidizing $\mathrm{Ph}^{*} \mathrm{SnCl}$ with $\mathrm{CCl}_{4}{ }^{[22]}$

$$
\begin{aligned}
& \mathrm{Ph}^{*} \mathrm{Li} \cdot \mathrm{OEt}_{2}+\mathrm{EX}_{4} \underset{-\mathrm{LiX}}{\stackrel{\mathrm{Et}_{2} \mathrm{O}}{\longrightarrow}} \mathrm{Ph}^{*} \mathrm{EX}_{3} \\
& \text { 1a: } \mathrm{E}=\mathrm{Sn}, \mathrm{X}=\mathrm{Cl} \\
& \text { 1b: } \mathrm{E}=\mathrm{Sn}, \mathrm{X}=\mathrm{Br} \\
& \text { 2: } \mathrm{E}=\mathrm{Ge}, \mathrm{X}=\mathrm{Cl}
\end{aligned}
$$

1a crystallizes in the triclinic space group $P \overline{1}$, and $\mathbf{2}$ crystallizes in the orthorhombic space group $C 222_{1}$. The molecular structure of $\mathbf{1 a}$ and $\mathbf{2}$ is shown in Figure 1. The structure of $\mathbf{2}$ is disordered due to contamination of the product with $\mathrm{Ph} * \mathrm{GeCl}$. The geometry about the group 14 element atom is a distorted tetrahedron with the chloride ligands pinched toward each other and away from the $\mathrm{Ph}^{*}$ ligand, presumably a result of the bulkiness of the $\mathrm{Ph}^{*}$ ligand.

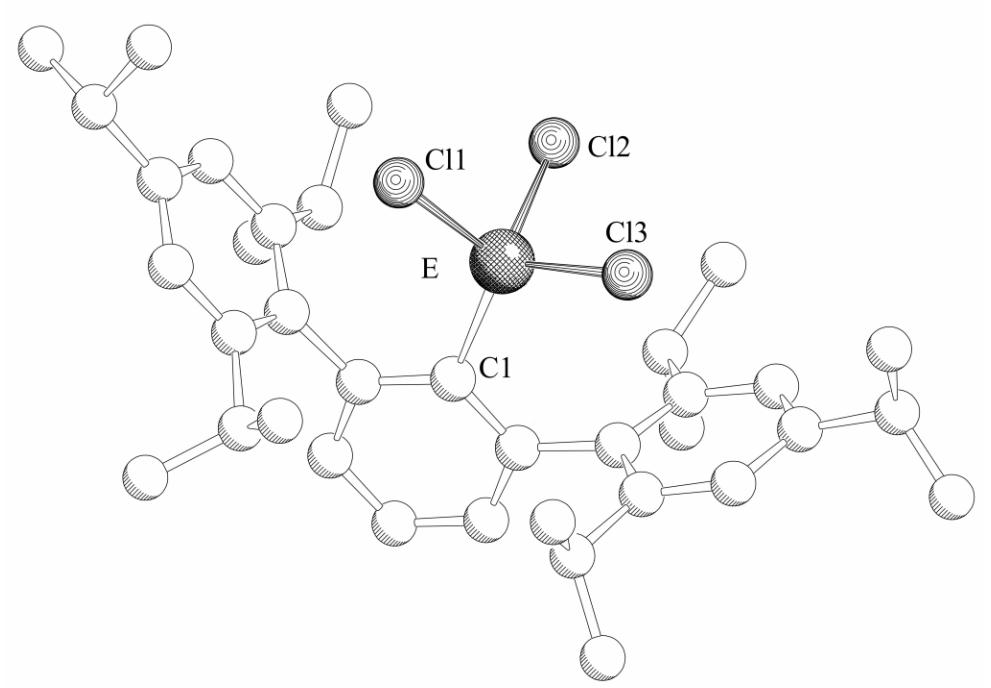

Figure 1. Molecular structure of $\mathrm{Ph}^{*} \mathrm{ECl}_{3}(1 \mathrm{a}: \mathrm{E}=\mathrm{Sn}, \mathbf{2}: \mathrm{E}=\mathrm{Ge})$ in the crystal. $\mathrm{H}$ atoms are omitted for clarity. Selected bond lengths $[\AA]$ and angles $\left[{ }^{\circ}\right]$ for 1a: Sn-C1 2.155(5), Sn-Cl1 2.322(3), Sn-Cl2 2.321(3), Sn-Cl3 2.328(2); C1-Sn-Cl1 119.89(13), C1-Sn-Cl2 122.05(13), C1-Sn-Cl3 109.26(14), Cl1-Sn-Cl2 98.12(7), Cl1-Sn-Cl3 102.96(8), Cl2-Sn-Cl3 $101.67(8){ }^{[23]}$

Formation of group 14 element/phosphorus compounds: An interesting aspect of the synthesized reagents $\mathbf{1 a}$ and $\mathbf{2}$ is the potential use as starting materials for the synthesis of $\mathrm{Sn} / \mathrm{Ge}-\mathrm{P}$ compounds in the oxidation state +4 of the group 14 element. Compound 1a was treated with $\mathrm{LiP}\left(\mathrm{SiMe}_{3}\right)_{2} \cdot 1.8 \mathrm{THF}$ in $\mathrm{Et}_{2} \mathrm{O}$ at low temperature. The ${ }^{31} \mathrm{P}$ NMR spectrum of the crude reaction mixture reveals the formation of $\mathrm{Ph} * \operatorname{SnP}\left(\operatorname{SiMe}_{3}\right)_{2}(3)\left(\delta\left({ }^{31} \mathrm{P}\right)=-123.1 \mathrm{ppm}\right)$ and $\left(\mathrm{Me}_{3} \mathrm{Si}\right)_{2} \mathrm{PP}\left(\mathrm{SiMe}_{3}\right)_{2}\left(\delta\left({ }^{31} \mathrm{P}\right)=-216 \mathrm{ppm}^{[24]}\right)$ in an approximate $1: 1$ ratio as the main phosphorus-containing products (Eq. 2). As the reduction potential for Ge is generally lower 
than that for $\mathrm{Sn}, 2$ was reacted with $\mathrm{LiP}\left(\mathrm{SiMe}_{3}\right)_{2} \cdot 1.8 \mathrm{THF}$ in $\mathrm{Et}_{2} \mathrm{O}$ at low temperature in order to give $\mathrm{Ph}^{*} \mathrm{GeCl}_{2} \mathrm{P}\left(\mathrm{SiMe}_{3}\right)_{2}$. However, the same result was achieved and, along with of the formation of $\left(\mathrm{Me}_{3} \mathrm{Si}\right)_{2} \mathrm{PP}\left(\mathrm{SiMe}_{3}\right)_{2}$ as a side-product, $\mathrm{Ph} * \mathrm{GeP}\left(\mathrm{SiMe}_{3}\right)_{2}$ (4) was isolated (Eq. 2). Obviously, metal-halogen exchange reactions play a decisive role which is also unavoidable using higher reaction temperatures (up to $0{ }^{\circ} \mathrm{C}$ ). Similar results are obtained if reaction (2) is carried out under the conditions of the multiple P-P bond formation reactions, ${ }^{[25]}$ for which an excess of $\mathrm{LiP}\left(\mathrm{SiMe}_{3}\right)_{2}$ has to be present to assure the autometalation reaction of the silylphosphorus atom by $\mathrm{LiP}\left(\mathrm{SiMe}_{3}\right)_{2}$ under formation of $\mathrm{P}\left(\mathrm{SiMe}_{3}\right)_{3}$. In order to ascertain whether a heavier alkali-metal phosphanide can induce preferential salt elimination over reduction, the analogous reaction was carried out with $\mathbf{1 a}$ and $\mathrm{KP}\left(\mathrm{SiMe}_{3}\right)_{2}$. The ${ }^{31} \mathrm{P} \mathrm{NMR}$ spectrum of the crude reaction mixture reveals the same phosphorus-containing products as that with $\mathrm{LiP}\left(\mathrm{SiMe}_{3}\right)_{2} \cdot 1.8 \mathrm{THF}$.

$$
\begin{aligned}
& \mathrm{Ph}^{*} \mathrm{ECl}_{3}+3 \mathrm{LiP}\left(\mathrm{SiMe}_{3}\right)_{2} \underset{-3 \mathrm{LiX}}{\stackrel{\mathrm{Et}_{2} \mathrm{O}}{\longrightarrow}} \mathrm{Ph} * \mathrm{EP}\left(\mathrm{SiMe}_{3}\right)_{2}+\left(\mathrm{Me}_{3} \mathrm{Si}\right)_{2} \mathrm{P}-\mathrm{P}\left(\mathrm{SiMe}_{3}\right)_{2} \\
& \text { 3: } \mathrm{E}=\mathrm{Sn} \\
& \text { 4: } \mathrm{E}=\mathrm{Ge}
\end{aligned}
$$

The reduction of $\mathbf{1 a}$ and $\mathbf{2}$ by $\mathrm{LiP}\left(\mathrm{SiMe}_{3}\right)_{2}$ and $\mathrm{P}-\mathrm{P}$ bond formation are unexpected in light of the reports on the reaction of $\mathrm{Ph}^{*} \mathrm{SiF}_{3}$ with $\mathrm{LiP}\left(\mathrm{SiMe}_{3}\right)_{2}$ to give the silane-elimination product shown in scheme $1 .^{[17]}$ Clearly, the relative stability of divalent stannylenes and germylenes over silylenes plays a key role in the differing redox behavior of $\mathbf{1 a}$ and $\mathbf{2}$ in reactions with the lithium phosphanide.

A byproduct-free synthesis of $\mathbf{3}$ and $\mathbf{4}$ is achieved, if the corresponding group 14 starting material is already in the oxidation state +2 . Thus, $\mathrm{Ph} * \mathrm{ECl}\left(\mathrm{E}=\mathrm{Sn},{ }^{[26]} \mathrm{Ge}\right)$ were treated with $\mathrm{LiP}\left(\mathrm{SiMe}_{3}\right)_{2} \cdot 1.8 \mathrm{THF}$ in $n$-hexane at low temperature. According to the ${ }^{31} \mathrm{P} \mathrm{NMR}$ spectra of the reaction mixtures only $\mathrm{Ph} * \operatorname{SnP}\left(\mathrm{SiMe}_{3}\right)_{2}(3)\left(\delta\left({ }^{31} \mathrm{P}\right)=-123.1 \mathrm{ppm}\right)$ and $\mathrm{Ph} * \mathrm{GeP}\left(\mathrm{SiMe}_{3}\right)_{2}$ (4) $\left(\delta\left({ }^{31} \mathrm{P}\right)=-48.5 \mathrm{ppm}\right)$, respectively, are detected as the main phosphorus-containing products along with traces of $\mathrm{HP}\left(\mathrm{SiMe}_{3}\right)_{2}\left(\delta\left({ }^{31} \mathrm{P}\right)=-236.3 \mathrm{ppm}\right)$, resulting from hydrolysis of $\mathrm{LiP}\left(\mathrm{SiMe}_{3}\right)_{2}$ (Eq. 3). From these reactions X-ray quality violet crystals of $\mathbf{3}$ and dark red crystals of $\mathbf{4}$ are obtained. Interestingly, the isolated yields are similar to the ones obtained by reaction (2).

$$
\begin{aligned}
& \mathrm{Ph} * \mathrm{ECl}+\operatorname{LiP}\left(\mathrm{SiMe}_{3}\right)_{2} \underset{-\mathrm{LiX}}{\stackrel{n \text {-hexane }}{\longrightarrow}} \mathrm{Ph} * \mathrm{EP}\left(\mathrm{SiMe}_{3}\right)_{2} \\
& \text { 4: } \mathrm{E}=\mathrm{Ge}
\end{aligned}
$$

The molecular structure of the compounds $\mathbf{3}$ and $\mathbf{4}$ are depicted in Figure 2. $\mathbf{3}$ crystallizes in the triclinic space group $P \overline{1}$ and $\mathbf{4}$ in the monoclinic space group $P 2_{1} / c$. In the crystal structure 
of $\mathrm{Ph} * \mathrm{EP}\left(\mathrm{SiMe}_{3}\right)_{2}(\mathbf{3}: \mathrm{E}=\mathrm{Sn}, \mathbf{4}: \mathrm{E}=\mathrm{Ge})$ the group 14 atom possesses a coordination number of two and lies in a bent geometry $\left(\mathrm{C}_{\mathrm{ipso}}-\mathrm{Ge}-\mathrm{P}: 106.88^{\circ}, \mathrm{C}_{\mathrm{ipso}}-\mathrm{Sn}-\mathrm{P}: 105.56(9)^{\circ}\right)$, which is a characteristic feature for structurally characterized stannylene/germylene compounds. The phosphorus atom is located in a distorted trigonal-pyramidal geometry between the group 14 atom and two silicon atoms. Since the $\mathrm{P}$ atom does not approach planarity, it can be concluded that the phosphorus lone pair does not participate significantly in donation to the group 14 element center. This correlates well with the tin-phosphorus coupling constants of compound $3\left({ }^{1} J_{\mathrm{P} 117 \mathrm{Sn}}=1396 \mathrm{~Hz},{ }^{1} J_{\mathrm{P} 119 \mathrm{Sn}}=1453 \mathrm{~Hz}\right)$, which are well below the range for compounds known to exhibit tin-phosphorus double bonding $\left({ }^{1} J_{\mathrm{PSn}} \approx 2000 \mathrm{~Hz}\right)$. The bulky nature of the $\mathrm{Ph}^{*}$ ligand allows the isolation of the terminal stannylene phosphanide $\mathbf{3}$ and the terminal germylene phosphanide 4. This is in contrast to the well-established field of phosphastannylenes and -germylenes usually representing phosphanido-bridged dimers ${ }^{[27]}$ or donor-stabilised monomers. ${ }^{[28]}$

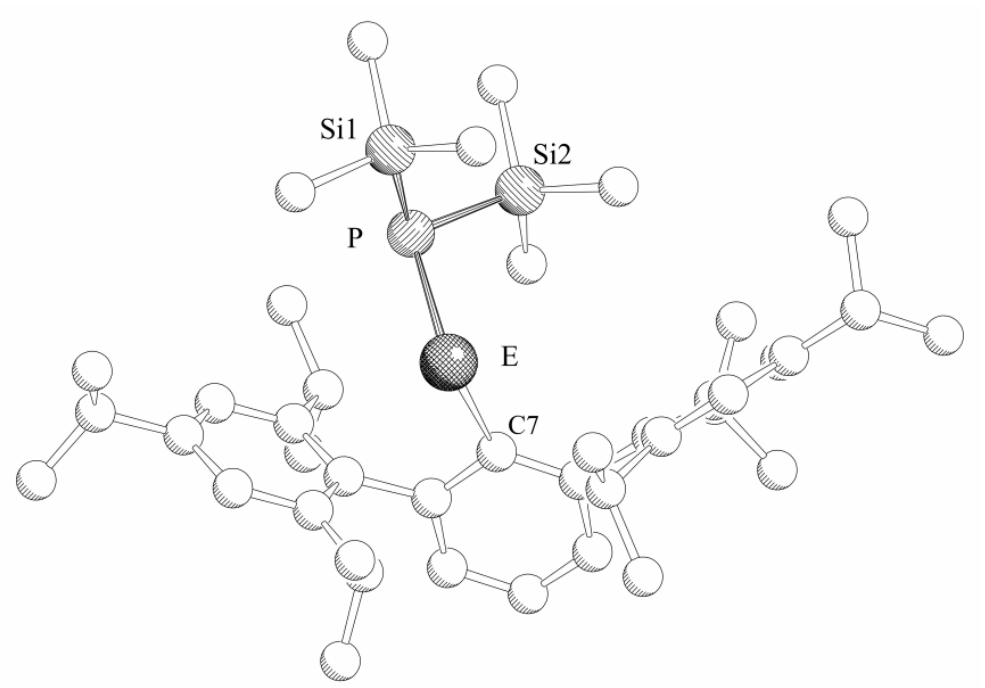

Figure 2. Molecular structures of $\mathrm{Ph} * \mathrm{EP}\left(\mathrm{SiMe}_{3}\right)_{2}(3: \mathrm{E}=\mathrm{Sn}, \mathrm{4}: \mathrm{E}=\mathrm{Ge})$ in the crystal. $\mathrm{H}$ atoms are omitted for clarity. Selected bond lengths $[\AA]$ and angles $\left[{ }^{\circ}\right]$ for 3: C7-Sn 2.229(3), Sn-P 2.527(1), P-Si1 2.244(2), P-Si2 2.243(4); C7-Sn-P 105.61(8), Sn-P-Si1 97.40(5), SnP-Si2 110.02(5), Si1-P-Si2 110.58(6). Selected bond lengths [ $[\AA]$ and angles [ $\left.{ }^{\circ}\right]$ for 4: C7-Ge 2.018(5), Ge-P 2.291(4), P-Si1 2.240(5), P-Si2 2.248(1); C7-Ge-P 106.89(5), Ge-P-Si1 119.53(2), Ge-P-Si2 97.49(2), Si1-P-Si2 109.87(3).

Reactivity of $\mathbf{P h} * \operatorname{SnP}\left(\mathrm{SiMe}_{3}\right)_{2}$ (3): Given the wealth of oxidative reactions of bivalent tin amides with organic halides, transition-metal halides, ${ }^{[29]}$ acid chlorides/anhydrides, ${ }^{[30]}$ and chalcogens, ${ }^{[31]}$ among others, to give well-defined $\mathrm{Sn}(\mathrm{IV})$ addition products, it is expected that chemical oxidation of $\mathrm{Ph} * \mathrm{SnP}\left(\mathrm{SiMe}_{3}\right)_{2}$ would be feasible. A variety of reagents bearing 
halides or pseudohalides were selected such that either spontaneous or thermal silane elimination would be viable upon oxidation and formation of $\mathrm{Ph} * \mathrm{Sn} \equiv \mathrm{P}$ or similar products would be conceivable. However, low-temperature reactions of $\mathrm{Ph} * \mathrm{SnP}\left(\mathrm{SiMe}_{3}\right)_{2}$ with $\mathrm{C}_{2} \mathrm{Cl}_{6}$, $\mathrm{Cp}_{2} \mathrm{Ti}(\mathrm{OTf})_{2}, \quad \mathrm{Hg}(\mathrm{OTf})_{2}, \quad \mathrm{Tl}\left(\mathrm{OOCCF}_{3}\right)_{3}$, benzoyl chloride, $\mathrm{Me}_{3} \mathrm{NO}$, and tropylium tetrafluoroborate each results in cleavage of the $\mathrm{Sn}-\mathrm{P}$ bond and generation of an intractable mixture of products, according to ${ }^{31} \mathrm{P}$ NMR spectra of the respective crude reaction mixtures. Reaction of $\mathrm{Ph} * \mathrm{SnP}\left(\mathrm{SiMe}_{3}\right)_{2}$ with $\mathrm{BrCH}_{2} \mathrm{CH}_{2} \mathrm{Br}$ at low temperature results in gradual discoloration of the violet solution to clear beige. The ${ }^{31} \mathrm{P}$ NMR spectrum reveals a main phosphorus-containing product $(>65 \%)$ at $\delta-167.2 \mathrm{ppm}$ with tin satellites $\left({ }^{1} J_{\mathrm{P}} 1{ }^{17} \mathrm{Sn}=1719\right.$ $\mathrm{Hz},{ }^{1} J_{\mathrm{P} 119 \mathrm{Sn}}=1799 \mathrm{~Hz}$ ). Work-up of the solution and crystallization from $n$-hexane afforded only colourless crystals of $\mathrm{Ph} * \mathrm{Br},{ }^{[32]}$ as identified by a X-ray diffraction experiment.

Reactivity of $\mathbf{P h} * \mathbf{S n C l}(5)$ : Moreover, the reactivity of the divalent compound $\mathrm{Ph} * \mathrm{SnCl}(5)$ was of interest and the reactions shown in scheme 2 were carried out.

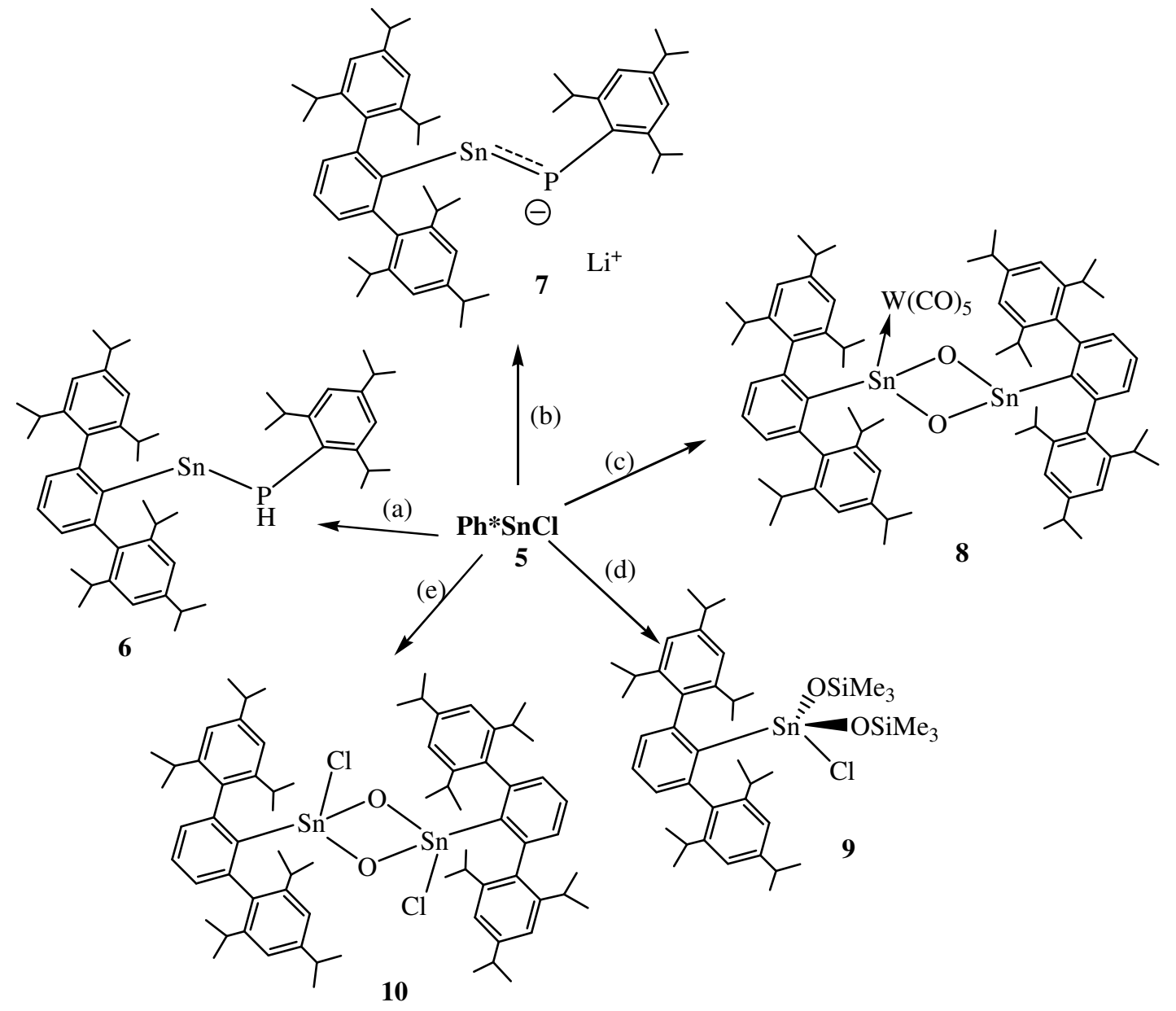

Scheme 2. Reactivity of $\mathrm{Ph} * \mathrm{SnCl}$ (5) with (a) $\mathrm{LiP}(\mathrm{H}) \mathrm{Trip}$ in $\mathrm{Et}_{2} \mathrm{O}$ at $-78{ }^{\circ} \mathrm{C}$; (b) $\mathrm{Li}_{2} \mathrm{PTrip}$ in $\mathrm{Et}_{2} \mathrm{O}$ at $-78{ }^{\circ} \mathrm{C}$; (c) $\mathrm{Li}\left[\mathrm{H}_{2} \mathrm{PW}(\mathrm{CO})_{5}\right]$ in n-hexane at $-78{ }^{\circ} \mathrm{C}$; (d) $\mathrm{Me}_{3} \mathrm{SiO}-\mathrm{OSiMe}_{3}$ in $\mathrm{Et}_{2} \mathrm{O}$ at 0 ${ }^{\circ} \mathrm{C}$; (e) $\mathrm{Me}_{3} \mathrm{NO} \mathrm{Et}{ }_{2} \mathrm{O}$ at $0{ }^{\circ} \mathrm{C}$. 
The reaction of 5 with $\mathrm{LiP}(\mathrm{H})$ Trip was carried out in $\mathrm{Et}_{2} \mathrm{O}$ at low temperature and afforded the monomeric arylstannylene phosphanide, $\mathrm{Ph} * \mathrm{SnP}(\mathrm{H})$ Trip $(6)$, with a Trip group and a reactive proton at the phosphorus atom. The ${ }^{31} \mathrm{P}\left\{{ }^{1} \mathrm{H}\right\}$ NMR spectrum of the crude reaction mixture reveals a relatively clean reaction with a slightly broadened main signal (ca. 70\%, $\left.\Delta v_{1 / 2}=150 \mathrm{~Hz}\right)$ attributable to $6\left(\delta=-70.9 \mathrm{ppm},{ }^{1} J_{\mathrm{P} 117 / 119 \mathrm{Sn}}=934 \mathrm{~Hz}\right)$, which is split into a doublet upon proton coupling $\left({ }^{1} J_{\mathrm{PH}}=186 \mathrm{~Hz}\right)$, along with traces of Trip $(\mathrm{H}) \mathrm{P}-\mathrm{P}(\mathrm{H}) \operatorname{Trip}(\delta=-$ $113.9 \mathrm{ppm})$ and $\mathrm{TripPH}_{2}(\delta=-158.3 \mathrm{ppm})$ as the only other phosphorus-containing products. The color of the proposed product $\mathbf{6}$ is intense violet, the same color as for the analogous bis(trimethylsilyl)phosphanide 3. In the ${ }^{31} \mathrm{P}\left\{{ }^{1} \mathrm{H}\right\}$ NMR spectrum of $\mathbf{6}$ a singlet with unresolved ${ }^{117 / 119} \mathrm{Sn}$ satellites is observed, which in the proton-coupled ${ }^{31} \mathrm{P}$ NMR splits into a doublet with two sets of unresolved ${ }^{117 / 119} \mathrm{Sn}$ satellites. The observation of unresolved ${ }^{117 / 119} \mathrm{Sn}$ satellites is reminiscent of the poorly resolved satellites observed in the ${ }^{31} \mathrm{P}$ signal for $\mathbf{5}$. Owing to the same excellent solubility of the byproducts compound $\mathbf{6}$ can not be isolated in analytically pure form.

Experiments aimed at deprotonating in situ generated 6 with $n \mathrm{BuLi}$ produced a mixture of unidentified products according to ${ }^{31} \mathrm{P}$ NMR. In recognition of the possibility of nucleophilic attack of $n \mathrm{BuLi}$ on the tin center, a route was chosen to circumvent the direct use of $n \mathrm{BuLi}$ with the stannylene. Thus, $\mathrm{TripPH}_{2}$ was twice deprotonated by $n \mathrm{BuLi}$, and the resulting doubly lithiated phosphanide $\mathrm{Li}_{2} \mathrm{PTrip}$ was added to 5. According to ${ }^{31} \mathrm{P} \mathrm{NMR}$, a mixture of products was generated by this protocol, from which Trip $(\mathrm{H}) \mathrm{P}-\mathrm{P}(\mathrm{H})$ Trip could be identified (ca. 20\%). The main product (ca. 40\%) was observed as a broad downfield signal proposed tentatively to be $\mathrm{Li}^{+}\left[\mathrm{Ph} * \mathrm{SnPTrip}^{-}(7)\left(\delta\left({ }^{31} \mathrm{P}\right)=229.7 \mathrm{ppm}, \Delta v_{1 / 2}=280 \mathrm{~Hz},{ }^{1} J_{\mathrm{P} 117 \mathrm{Sn}}=1735\right.\right.$ $\mathrm{Hz},{ }^{1} J_{\mathrm{P} 119} \mathrm{Sn}=2004 \mathrm{~Hz}$ ). The broadness of the observed signal is a characteristic indicator for lithium-coordinated anions, where the lithium shifts rapidly between ion-contact and ionseparated forms. No $\mathrm{P}-\mathrm{H}$ coupling is observed in the proton-coupled spectrum. Attempts to produce 7 by lithiation of 6 with $n \mathrm{BuLi}$ did not result in the observation of the downfield signal observed in the reaction of $\mathrm{Ph}{ }^{*} \mathrm{SnCl}(5)$ with $\mathrm{Li}_{2} \mathrm{PT}$ Trip. The low-field ${ }^{31} \mathrm{P}$ NMR shift of the proposed compound 7 (scheme 2 ) and the large ${ }^{1} J_{\mathrm{P} 117 / 119}$ Sn coupling constants signify a situation of multiple bonding between tin and phosphorus. The bonding about tin and phosphorus in the anionic moiety $\left[\mathrm{Ph}^{*} \mathrm{SnPT} \text { rip }\right]^{-}$is isoelectronic to the neutral compound $\mathrm{Ph} * \mathrm{Sb}=\mathrm{PMes}$ with a known double bond. ${ }^{[33]}\left[\mathrm{Ph}^{*} \text { SnPTrip }\right]^{-}$can also be thought of as isolobal to the doubly reduced acetylene analogue $\left[\mathrm{Ph}^{*} \mathrm{Sn}=\mathrm{SnPh}^{*}\right]^{2-}$, which has been suggested as having a $\mathrm{Sn}=\mathrm{Sn}$ double bond, ${ }^{[34]}$ as well as isolobal to the general family of dipnictenes 
$\mathrm{RE}=\mathrm{ER}(\mathrm{E}=\mathrm{P}, \mathrm{As}, \mathrm{Sb})$, each with undisputed double-bond character. ${ }^{[35]}$ The bonding between $\mathrm{Sn}$ and $\mathrm{P}$ is tentatively represented in Scheme 2 with a bond order greater than one, with the possibility that double bonding is the more accurate description for anionic compounds of the form $\left[\mathrm{Ph}^{\mathrm{R}} \mathrm{SnPPh}^{\mathrm{R}}\right]^{-}$.

Theoretical Considerations for $\mathrm{Li}^{+}[\mathbf{P h} * \text { SnPTrip] }]^{-}$(7): A $\mathrm{Sn}(\mathrm{II})$ compound in which both the tin and phosphorus atoms are two-coordinate is so far unprecedented, as all known doubly bonded $\mathrm{Sn}=\mathrm{P}$ species are three-coordinate at the tin atom. As noted above, the $\mathrm{Sn}-\mathrm{P}$ bonding in the anionic compound 7 is expected to be isolobal to dianionic $\left[\mathrm{Ph}^{\mathrm{R}} \mathrm{SnSnPh}^{\mathrm{R}}\right]^{2-}$ or neutral $\left[\mathrm{Ph}^{\mathrm{R}} \mathrm{PPPh}^{\mathrm{R}}\right]$. Three interesting considerations for 7 are the energetically lowest molecular geometry about tin and phosphorus, the appearance of the frontier molecular orbitals, and the charge distribution within the anionic compound. Calculations were carried out on the model compound [ $\mathrm{PhSnPPh}]^{-}\left(7^{\prime}\right)$ using the Gaussian 03 program $^{[36]}$ at the DFT-B3LYP level with the SDD basis set consisting of an pseudorelativistic effective core potential for the Sn atom and Dunning/Huzinaga full double zeta basis set for all other atoms. In the current study, the lithium counterion is not considered in order to rule out influence of contacts between the lithium cation and anionic portions of $[\mathrm{PhSnPPh}]^{-}$.

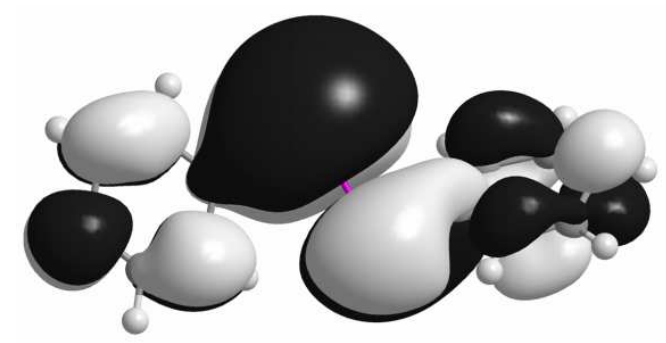

LUMO

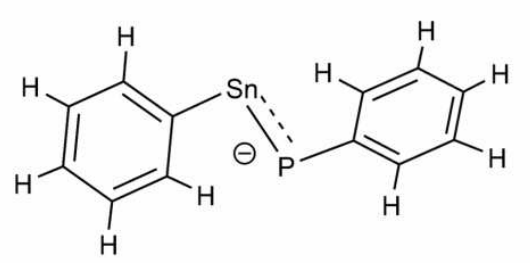

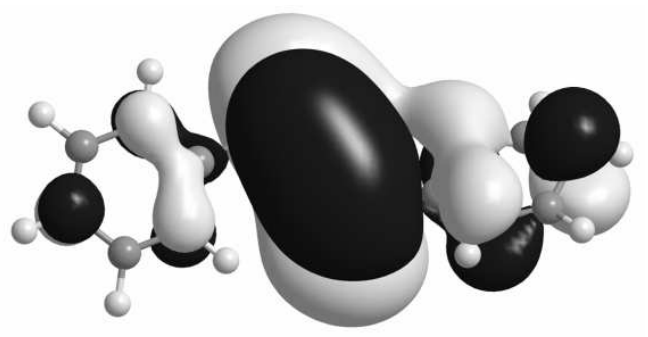

HOMO

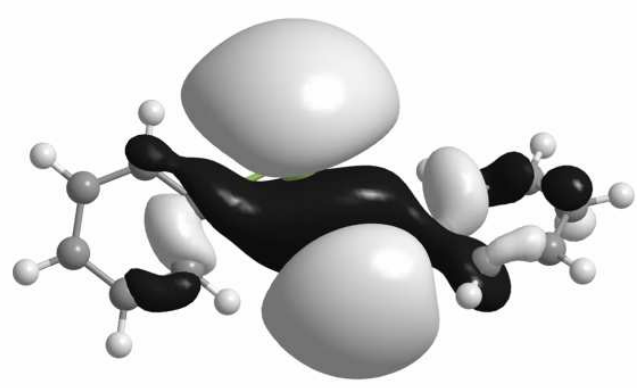

HOMO-1

Figure 3. Iso-surfaces of the molecular orbitals for model compound [PhSnPPh] $\left.{ }^{-} \mathbf{7}^{\prime}\right)$. Upper left: LUMO; upper right: HOMO; lower left: graphical representation of anion considered; lower right: HOMO-1. 
The calculated structure of $[\mathrm{PhSnPPh}]^{-}$results in a trans-bent orientation of the phenyl substituents, which are slightly rotated relative to one another. The $\mathrm{C}_{\text {aryl }}-\mathrm{Sn}-\mathrm{P}$ and $\mathrm{Sn}-\mathrm{P}-\mathrm{C}_{\text {aryl }}$ angles in the optimized structure are $94.3^{\circ}$ and $103.2^{\circ}$, respectively. The angle about tin is considerably less obtuse than that in compound $3\left(105.56(9)^{\circ}\right)$, which could be attributed partially to the lower degree of steric bulk of $\mathrm{Ph}$ in comparison to $\mathrm{Ph}^{*}$. In Figure 3, the orbital isosurfaces for the frontier molecular orbitals are represented. The HOMO-1 (lower right) and HOMO (upper right) are of the bonding $\sigma$ and $\pi$ types, respectively, while the LUMO (upper left) is of the antibonding $\pi^{*}$ type. This situation is in agreement with the view of [PhSnPPh] having an $\mathrm{Sn}=\mathrm{P}$ double bond, though a concrete bond order cannot be assigned from these data. Furthermore, the molecular orbital representations reveal participation of the phenyl groups in the Sn-P bonding, particularly in the $\pi$-type and $\pi^{*}$-type orbitals, which is an indication of the stabilization which aryl groups offer to such multiply bonded systems. The Mulliken atomic charges in [PhSnPPh] $]^{-}$are calculated to be +0.12 for $\mathrm{Sn}$ and -0.25 for $\mathrm{P}$, while the remainder of the overall negative charge is distributed throughout the phenyl groups (av. charge on $\mathrm{C}$ : -0.23 ; av. charge on $\mathrm{H}$ : +0.20 ). The negative charge is weighted slightly more heavily toward the phosphorus-bound phenyl group (total $=-0.45$ ) than the tin-bound phenyl group (total $=-0.42$ ). The distribution of charge throughout the phenyl groups also demonstrates an aspect of the stabilization of aryl groups in multiply bonded anionic maingroup moieties.

Synthesis of tin-oxo derivatives: In order to probe the possibility of preparing a monomeric aryl stannylene with reactive $\mathrm{P}-\mathrm{H}$ bonds and without organic substituents at phosphorus, 5 was treated with $\mathrm{Li}\left[\mathrm{H}_{2} \mathrm{PW}(\mathrm{CO})_{5}\right]$ in $n$-hexane at $-78^{\circ} \mathrm{C}$ (scheme 2). The orange solution gradually became light red, and overnight stirring produced a beige-red solution. The ${ }^{31} \mathrm{P}\left\{{ }^{1} \mathrm{H}\right\}$ and ${ }^{31} \mathrm{P}$ NMR spectra for the crude reaction mixture reveal an array of 6 main phosphoruscontaining products in approximately equal proportions. One signal at $-187 \mathrm{ppm}$ bears tungsten satellites $\left({ }^{1} J_{\mathrm{PW}}=213 \mathrm{~Hz}\right)$ and is split into a quartet in the proton-coupled spectrum $\left({ }^{1} J_{\mathrm{PH}}=342 \mathrm{~Hz}\right)$ and is assigned as $\left[\mathrm{H}_{3} \mathrm{PW}(\mathrm{CO})_{5}\right]$. Each of the remaining five signals is split into triplets in the proton-coupled ${ }^{31} \mathrm{P}$ NMR spectra, indicating preservation of the intact $\mathrm{PH}_{2}$ unit. Decanting the mother liquor away from $\left[\mathrm{H}_{3} \mathrm{PW}(\mathrm{CO})_{5}\right]$ and storage of the highly concentrated solution at $-25^{\circ} \mathrm{C}$ for several weeks resulted in deposition of a few orange crystals, alongside co-crystallized $\left[\mathrm{H}_{3} \mathrm{PW}(\mathrm{CO})_{5}\right]$, from which one was selected for an X-ray diffraction experiment. [Ph* $\left.\operatorname{Sn}\left\{\mathrm{W}(\mathrm{CO})_{5}\right\}(\mu-\mathrm{O})_{2} \mathrm{SnPh}^{*}\right](\mathbf{8})$ crystallizes in the orthorhombic space group Pnma, in which one of the tin atoms is coordinated to a tungsten pentacarbonyl 
fragment. The molecular structure and selected bond lengths and angles are shown in Figure 4. The formation of $\mathbf{8}$ comes apparently as a result of contamination with moisture or oxygen, likely due to the excess handling and long crystallization period. The most notable feature of $\mathbf{8}$ is the coordination of tin to the $\mathrm{W}(\mathrm{CO})_{5}$ fragment, which had been introduced into the reaction mixture as a phosphorus-coordinated adduct. The bridging oxygen atoms are slightly bowed in the same direction and the $\mathrm{Ph}^{*}$ groups lie in trans-bent arrangement.

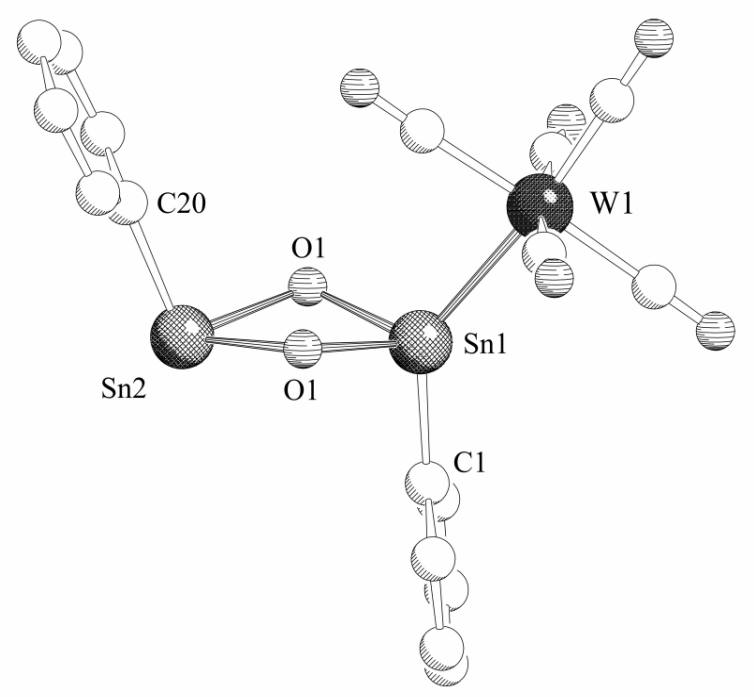

Figure 4. Molecular structure of $\left[\mathrm{Ph} * \operatorname{Sn}\left\{\mathrm{W}(\mathrm{CO})_{5}\right\}(\mu-\mathrm{O})_{2} \mathrm{SnPh}^{*}\right](\mathbf{8})$ in the crystal. The $\mathrm{H}$ atoms and $o$-Trip groups are omitted for clarity. Selected bond lengths $[\AA \AA]$ and angles $\left[^{\circ}\right]$ : W1-Sn1 2.743(2), Sn1-C1 2.183(9), Sn2-C20 2.183(9), Sn1-O1 2.140(5), Sn2-O1 2.224(5), $\mathrm{W} 1-\mathrm{C}_{\text {trans }} 1.978(15), \mathrm{W} 1-\mathrm{C}_{\mathrm{cis}} 2.058(14)$ (mean value is given); O1-Sn1-O1 73.0(3), O1Sn2-O1 69.9(3), O1-Sn1-W1 111.57(14), Sn1-O1-Sn2 105.6(2), C1-Sn1-W1 137.9(3), C1-Sn1-O1 101.9(3), C20-Sn2-O1 99.2(3).

The large $\mathrm{C}_{\text {aryl }}-\mathrm{Sn} 1-\mathrm{W} 1$ angle $\left(137.9(3)^{\circ}\right)$ illustrates the steric crowding about $\mathrm{Sn} 1$ in $\mathbf{8}$ as does the pronounced pinching of the oxygen atoms about the tin atoms (O1-Sn1-O1: 73.0(3) ${ }^{\circ}$; O1-Sn2-O1: 69.9(3) $\left.{ }^{\circ}\right)$. The Sn-W bond length $(2.743(2) \AA)$ falls within the range of other known tungstenpentacarbonyl-coordinated stannylene complexes (compare:

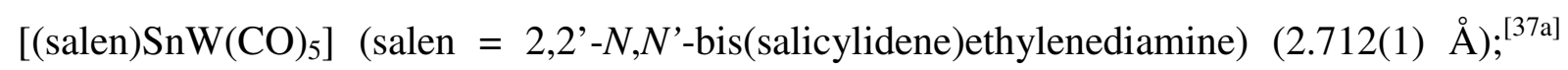
$\left[(\mathrm{CO})_{5} \mathrm{WSn}(\mathrm{Cl}) \mathrm{Fe}(\mathrm{CO})_{4}\right]_{2}{ }^{2-}(2.799(1) \AA)^{[}{ }^{[37 \mathrm{~b}]}\left[\mathrm{Mes} *(\mathrm{R}) \mathrm{Sn}=\mathrm{W}(\mathrm{CO})_{5}\right] \quad\left(\mathrm{R}=\mathrm{CH}_{2} \mathrm{CMe}_{2} \mathrm{C}_{6} \mathrm{H}_{3}\right.$ $\left.t \mathrm{Bu}_{2}-3,5\right)(2.751(1) \AA)^{[37 \mathrm{c}]} ;\left[\left(o-\mathrm{C}_{6} \mathrm{H}_{4} \mathrm{CH}_{2} \mathrm{E}\right)_{2} \mathrm{SnW}(\mathrm{CO})_{5}\right]\left(\mathrm{E}=\mathrm{NMe}_{2}, \mathrm{PPh}_{2}\right)$ (2.749(1) and 2.762(1) $\left.\AA^{[37 \mathrm{~d}]}\right)$. A most conspicuous feature of the structure of $\mathbf{8}$ is the 3-coordinate tin atom, $\mathrm{Sn} 2$. While the donation to $\mathrm{W}(\mathrm{CO})_{5}$ designates $\mathrm{Sn} 1$ as a divalent center, the logical description of $\mathrm{Sn} 2$ as tetravalent does not agree well with $\mathrm{Sn} 2$ being only 3-coordinate, unless multiple Sn-O bonding is involved. The Sn-O bond lengths (Sn1-O1: 2.140(5) A, Sn2-O1: 
2.224(5) $\AA$ ) differ slightly from one another, but are considerably longer than the Sn-O bonds in cyclo-[Trip $\mathrm{SnO}_{3}(1.956(2) \AA, 1.970(2) \AA)$, which contains exclusively Sn-O single bonds. ${ }^{[38]}$ The elongated $\mathrm{Sn}-\mathrm{O}$ bonds in $\mathbf{8}$ can be attributed to the steric crowding about the tin centers caused by the bulky terphenyl substituents and the $\mathrm{W}(\mathrm{CO})_{5}$ unit. Thus, the most logical bonding scheme which fits the existence of the 3-coordinate tin centre is one in which the $\mathrm{Sn} 2-\mathrm{O}$ bond is represented by a double bond, and this oxygen ligand further donates to the stannylene centre, Sn1. One resonance form for this description is depicted in Scheme 3. The structure proposal of $\mathbf{8}$ in Scheme 3 is not consistent with the $\mathrm{Sn}-\mathrm{O}$ bond lengths, since the $\mathrm{Sn} 2-\mathrm{O}$ bond should be a multiple bond by this description but is longer than the $\mathrm{Sn} 1-\mathrm{O}$ bond. An explanation for this discrepancy may be the constrained geometry of the core in $\mathbf{8}$ caused by steric repulsion from the $\mathrm{W}(\mathrm{CO})_{5}$ group. However, the existence of a bis-hydroxo derivative 8a (scheme 3) can not be excluded, since a residue electron density is found close to the $\mathrm{O} 1$ atoms (Figure 4). Yet, the experimental distance found of $0.58 \AA$ is too short for an $\mathrm{O}-\mathrm{H}$ bond. Nevertheless, in view of a recent report on hydroxo-bridged Sn(II) dimers $\left(\mathrm{Ph}^{\prime} \mathrm{SnOH}\right)_{2}\left(\mathrm{Ph}^{\prime}=\mathrm{C}_{6} \mathrm{H}_{3}-2,6\left(\mathrm{C}_{6} \mathrm{H}_{3}-2,6-i \mathrm{Pr}_{2}\right)_{2}\right)$ by Power et al., ${ }^{[39]}$ for which $\mathrm{Sn}-\mathrm{O}$ bond lengths of 2.145(2) and 2.149(1) $\AA$ were found, the existence of 8a is also an appropriate description.

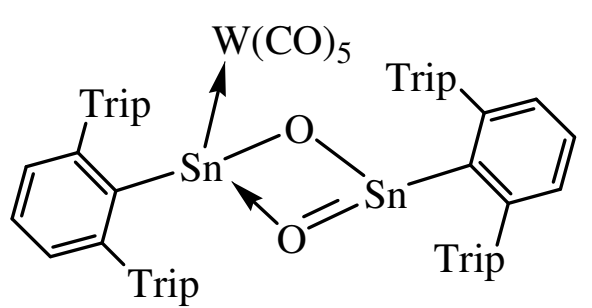

8

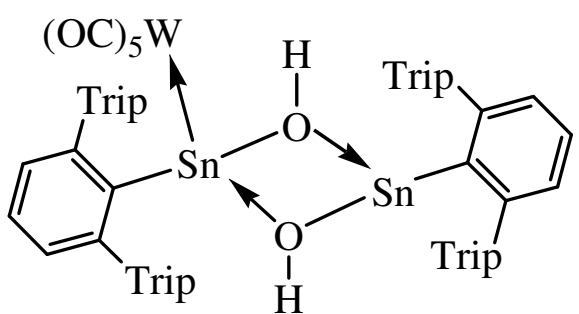

$8 \mathbf{a}$

Scheme 3. Proposed bonding scheme in $\mathrm{Sn}_{2} \mathrm{O}_{2}\left\{\mathrm{~W}(\mathrm{CO})_{5}\right\}$ core of 8 and its alternative existence as a bis-hydroxy derivative $\mathbf{8 a}$.

Treatment of 5 with trimethylsilylperoxide, $\mathrm{Me}_{3} \mathrm{SiOOSiMe}_{3},{ }^{[40]}$ at $0{ }^{\circ} \mathrm{C}$ in $\mathrm{Et}_{2} \mathrm{O}$ resulted in immediate discoloration of the orange solution (scheme 2). $\mathrm{Ph} * \mathrm{Sn}\left(\mathrm{OSiMe}_{3}\right)_{2} \mathrm{Cl}$ (9) was isolated as a sticky oil and is highly soluble in common hydrocarbons. The ${ }^{1} \mathrm{H}$ NMR spectrum of 9 reveals a sharp signal at $0.13 \mathrm{ppm}$ for the trimethylsiloxy groups along with a few neighboring peaks likely resulting from impurity or unreacted trimethylsilylperoxide. The $i \mathrm{Pr}$ protons on the tertiary carbon atoms overlap and give a broad multiplet. In the EI mass spectrum a peak corresponding to the molecular ion minus one methyl group is found, along with further peaks signalling successive loss of the silyloxy ligands and fragmentation of the 
$\mathrm{Ph}^{*}$ ligand. No higher peaks indicating a dimeric structure with bridging silyloxy ligands are found. Thus, the structure is proposed to be monomeric, as shown in Scheme 2.

In an attempt to prepare the kinetically stabilized heavier Group 14 acid halide analogue $\mathrm{Ph} * \mathrm{Sn}(\mathrm{O}) \mathrm{Cl}, 5$ was treated with solid trimethylamine $N$-oxide, $\mathrm{Me}_{3} \mathrm{NO}$, at $0{ }^{\circ} \mathrm{C}$ in $\mathrm{Et}_{2} \mathrm{O}$ (scheme 2). Immediately upon mixing the orange solution underwent rapid discoloration and colourless crystals of $\left[\mathrm{Ph}^{*} \mathrm{Sn}(\mu-\mathrm{O}) \mathrm{Cl}\right]_{2}(\mathbf{1 0})$ were isolated by crystallization from the filtered reaction mixture. $\mathbf{1 0}$ formally represents a dimerization of the targeted acid halide analogue, $\mathrm{Ph} * \mathrm{Sn}(\mathrm{O}) \mathrm{Cl}$, a compound class which has yet not been described experimentally for tin. The clean addition of oxygen to $\mathrm{Sn}$ (II) to form $\mathbf{1 0}$ stands in contrast to attempts to prepare a ketone analogue for tin by Power et al., in which the reaction of $\mathrm{Ph}_{2}{ }_{2} \mathrm{Sn}\left(\mathrm{Ph}{ }^{\prime}=\mathrm{C}_{6} \mathrm{H}_{3} \mathrm{Mes}_{2}-2,6\right)$ with $\mathrm{Me}_{3} \mathrm{NO}$ resulted in the formal addition of $\mathrm{H}_{2} \mathrm{O}$ to the expected product $\mathrm{Ph}_{2} \mathrm{Sn}=\mathrm{O}$ and led instead to the dihydroxy compound $\mathrm{Ph}_{2} \mathrm{Sn}(\mathrm{OH})_{2} \cdot{ }^{[41]} \mathbf{1 0}$ crystallizes in the triclinic space group $P \overline{1}$. The molecular structure and selected bond lengths and angles are shown in Figure 5.

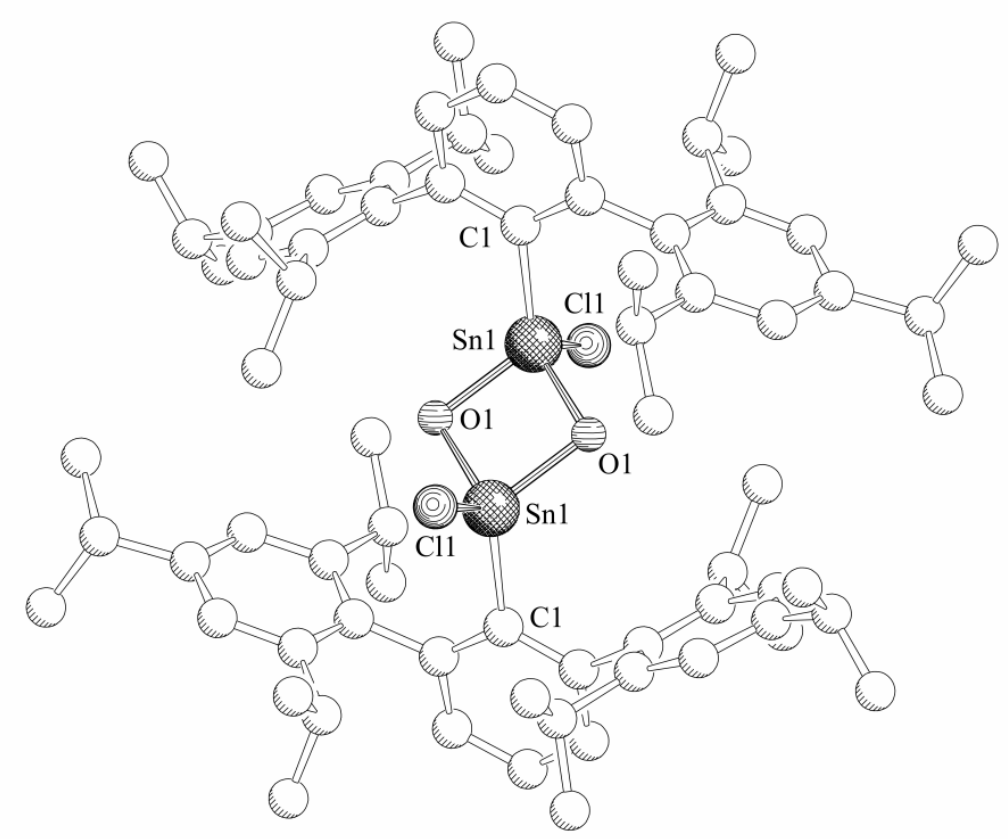

Figure 5. Molecular structure of $\left[\mathrm{Ph}^{*} \mathrm{Sn}(\mu-\mathrm{O}) \mathrm{Cl}\right]_{2}(\mathbf{1 0})$ in the crystal. $\mathrm{H}$ atoms are omitted for

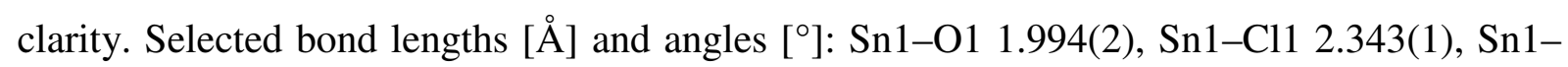
$\mathrm{C}_{\text {ipso }}$ 2.137(3); Sn1-O1-Sn1 95.38(9), O1-Sn1-O1 84.62(9), Cl1-Sn1-O1 108.47(6), Cl1Sn1-O1 106.36(7), C $\mathrm{C}_{\mathrm{ipso}}-\mathrm{Sn} 1-\mathrm{O} 1$ 117.28(10), $\mathrm{C}_{\mathrm{ipso}}-\mathrm{Sn} 1-\mathrm{O} 1$ 119.98(9), Cl1-Sn1-C $\mathrm{C}_{\mathrm{ipso}}$ 115.76(8).

The molecular structure of $\mathbf{1 0}$ is located on an inversion center, such that the central $\mathrm{Sn}_{2} \mathrm{O}_{2}$ unit is a planar rhombus and only one unique $\mathrm{Sn}-\mathrm{O}$ bond length results. The planarity of the 
$\mathrm{Sn}_{2} \mathrm{O}_{2}$ core mirrors that of $\left[\mathrm{R}_{2} \mathrm{Sn}(\mu-\mathrm{O})\right]_{2}\left(\mathrm{R}=\mathrm{CH}\left(\mathrm{SiMe}_{3}\right)_{2}\right)^{[42]}$ and analogues possessing heavier chalcogenide ligands, as in $\left[t \mathrm{Bu}_{2} \operatorname{Sn}(\mu-\mathrm{E})\right]_{2}(\mathrm{E}=\mathrm{S}, \mathrm{Se}, \mathrm{Te})^{[43]}$ or $\left[\left(\operatorname{Trip}_{2} \mathrm{Sn}\right)_{2}(\mu-\mathrm{O})(\mu-\right.$ $\mathrm{S})] .{ }^{[44]}$ However, while all $\mathrm{Sn}-\mathrm{O}$ bonds in $\mathbf{1 0}$ have the same length, the $\mathrm{Sn}-\mathrm{O}$ bonds in $\left[\left\{\left(\mathrm{Me}_{3} \mathrm{Si}\right)_{2} \mathrm{CH}\right\}_{2} \mathrm{Sn}(\mu-\mathrm{O})\right]_{2}$ are of varying lengths, such that a non-rhomboidal parallelogram form of the $\mathrm{Sn}_{2} \mathrm{O}_{2}$ core results. The $\mathrm{Sn}$ atoms are in distorted tetrahedral geometry with the $\mathrm{C}_{\mathrm{ipso}}-\mathrm{Sn} 1-\mathrm{O} 1$ angles $\left(117.28(10)^{\circ}, 119.98(9)^{\circ}\right)$ significantly larger than the $\mathrm{Cl}-\mathrm{Sn}-\mathrm{O}$ angles $\left(106.36(7)^{\circ}, 108.47(6)^{\circ}\right)$, likely a result of steric repulsion from the $\mathrm{Ph} *$ ligands. The $\mathrm{O}-\mathrm{Sn}-\mathrm{O}$ angles $\left(84.62(9)^{\circ}\right)$ are considerably more acute than the $\mathrm{Sn}-\mathrm{O}-\mathrm{Sn}$ angles $\left(95.38(9)^{\circ}\right)$ in $\mathbf{1 0}$. The $\mathrm{Sn}-\mathrm{O}$ bond distance $(1.994(2) \AA)$ is significantly shorter than those in compound 8 (2.140(5) $\AA, 2.224(5) \AA$ ) and compares well with the Sn-O bond lengths in cyclo[(Me $\left.\left.\mathrm{Mi}_{3}\right)_{3} \mathrm{CSn}(\mathrm{OH}) \mathrm{O}\right]_{3}\left(\mathrm{Sn}-\mathrm{O}_{\text {ring }}: 1.965 \AA\right.$; $\left.\mathrm{Sn}-\mathrm{O}_{\mathrm{OH}}: 1.968 \AA\right),{ }^{[45]}$ but is longer than those of $\left[\left\{\left(\mathrm{Me}_{3} \mathrm{Si}\right)_{2} \mathrm{CH}\right\}_{2} \mathrm{Sn}(\mu-\mathrm{O})\right]_{2}(1.94(2) \AA, 1.98(1) \AA)$. The $\mathrm{Sn}-\mathrm{C}_{\mathrm{ipso}}$ bond length $(2.137(3) \AA)$ is considerably shorter than the $\mathrm{Sn}-\mathrm{C}_{\mathrm{ipso}}$ bond length (2.226(4) $\AA$ ) in $\mathbf{3}$, reflecting the difference in a tetravalent aryl stannane and a divalent aryl stannylene.

\section{Conclusions}

The results have shown that the reaction of tetravalent trichloro-germanium and -tin compounds containing a bulky terpenyl substituent $\mathrm{Ph} * \mathrm{ECl}_{3}$ with $\mathrm{LiP}\left(\mathrm{SiMe}_{3}\right)_{2}$ do not result in low-valent products possessing element-phosphorus triple bonds. Instead, redox reactions proceed and the divalent group 14/phosphanide products $\mathrm{Ph} * \mathrm{EP}\left(\mathrm{SiMe}_{3}\right)_{2}(\mathrm{E}=\mathrm{Sn}, \mathrm{Ge})$ have been isolated and structurally characterised. These products were also obtained by using the divalent compounds $\mathrm{Ph} * \mathrm{ECl}$. Comprehensive studies of the reaction behaviour of $\mathrm{Ph} * \mathrm{SnCl}$ were carried out resulting in novel low valent tin-phosphorus and tin-oxygen derivatives. Some of them reveal unprecedented bonding features. The reaction pattern shown clearly reveals the high potential of the bulky terphenyl substituent in low-valent group 14 element chemistry. 
Table 1. Crystallographic Data for compound 1a, 2 and 3.

\begin{tabular}{|c|c|c|c|c|c|c|}
\hline & $1 \mathbf{a}$ & 2 & 3 & 4 & 8 & 10 \\
\hline Empirical formula & $\mathrm{C}_{36} \mathrm{Cl}_{3} \mathrm{H}_{49} \mathrm{Sn}$ & $\mathrm{C}_{36} \mathrm{Cl}_{2} \mathrm{H}_{49} \mathrm{Ge}$ & $\mathrm{C}_{42} \mathrm{H}_{67} \mathrm{PSi}_{2} \mathrm{Sn}$ & $\mathrm{C}_{42} \mathrm{H}_{67} \mathrm{PSi}_{2} \mathrm{Ge}$ & $\mathrm{C}_{77} \mathrm{H}_{98} \mathrm{O}_{7} \mathrm{Sn}_{2} \mathrm{~W}$ & $\mathrm{C}_{72} \mathrm{Cl}_{2} \mathrm{H}_{98} \mathrm{O}_{2} \mathrm{Sn}_{2}$ \\
\hline Formula mass $/ \mathrm{g} \mathrm{mol}^{-1}$ & 706.81 & 625.26 & 777.82 & 731.72 & 1556.81 & 1303.82 \\
\hline $\mathrm{T} / \mathrm{K}$ & $203(2)$ & $123(1)$ & $200(1)$ & $123(1)$ & 203(1) & $173(1)$ \\
\hline Crystal dimensions /mm & $0.12 \times 0.10 \times 0.03$ & $0.29 \times 0.09 \times 0.08$ & $0.20 \times 0.20 \times 0.02$ & $0.24 \times 0.11 \times 0.11$ & $0.20 \times 0.20 \times 0.06$ & $0.22 \times 0.16 \times 0.12$ \\
\hline Crystal system & Triclinic & Orthorhombic & Triclinic & Monoclinic & Orthorhombic & Triclinic \\
\hline Space group & $P \overline{1}$ & $C 222_{1}$ & $P \overline{1}$ & $P 2_{1} / c$ & Pnma & $P \overline{1}$ \\
\hline$a(\AA)$ & $8.479(1)$ & $11.017(9)$ & $9.280(1)$ & $15.279(7)$ & $18.983(4)$ & $9.887(9)$ \\
\hline$b(\AA)$ & $13.799(3)$ & $12.212(6)$ & $13.240(3)$ & $16.004(8)$ & $18.340(4)$ & $12.945(9)$ \\
\hline$c(\AA)$ & $16.691(3)$ & $25.526(3)$ & $19.576(4)$ & $18.090(5)$ & $23.227(5)$ & $15.833(8)$ \\
\hline$\alpha\left(^{\circ}\right)$ & $70.59(3)$ & 90 & $83.19(3)$ & 90 & 90 & $66.61(8)$ \\
\hline$\beta\left(^{\circ}\right)$ & $85.67(3)$ & 90 & $88.44(3)$ & $103.60(9)$ & 90 & $87.09(8)$ \\
\hline$\gamma\left({ }^{\circ}\right)$ & $72.24(3)$ & 90 & $70.83(3)$ & 90 & 90 & $86.62(5)$ \\
\hline$V\left(\AA^{3}\right)$ & $1753.4(8)$ & $3434.7(6)$ & $2255.7(9)$ & $4299.8(2)$ & $8086(3)$ & $1856.3(3)$ \\
\hline$Z$ & 2 & 4 & 2 & 4 & 4 & 1 \\
\hline$D_{\text {calc }} / \mathrm{g} \cdot \mathrm{cm}^{-3}$ & 1.339 & 1.209 & 1.145 & 1.130 & 1.279 & 1.166 \\
\hline$\mu / \mathrm{mm}^{-1}$ & 0.980 & 2.788 & 0.680 & 2.031 & 2.077 & 0.783 \\
\hline$F(000)$ & 732 & 1324 & 824 & 1576 & 3160 & 680 \\
\hline radiation & $\mathrm{Mo}_{\mathrm{K} \alpha}$ & $\mathrm{Cu}_{\mathrm{K} \alpha}$ & $\mathrm{Mo}_{\mathrm{K} \alpha}$ & $\mathrm{Cu}_{\mathrm{K} \alpha}$ & $\mathrm{Mo}_{\mathrm{K} \alpha}$ & $\mathrm{Mo}_{\mathrm{K} \alpha}$ \\
\hline$\theta$ range & $2.40-25.94$ & $3.41-62.21$ & $2.32-26.00$ & $3.41-66.73$ & $2.06-25.90$ & $2.46-25.81$ \\
\hline reflections collected & 12082 & 12127 & 16260 & 20851 & 34356 & 13161 \\
\hline unique reflections & 6320 & 2639 & 8232 & 7497 & 7703 & 6646 \\
\hline GOF on $F^{2}$ & 1.034 & 1.094 & 1.029 & 1.062 & 1.056 & 0.949 \\
\hline$R_{\text {int }}$ & 0.0617 & 0.0485 & 0.0359 & 0.0272 & 0.0750 & 0.0234 \\
\hline$R_{1}^{[\mathrm{a}]}[I>2 s(I)]$ & 0.0532 & 0.0927 & 0.0409 & 0.0331 & 0.0554 & 0.0317 \\
\hline $\mathrm{w} R_{2}{ }^{[\mathrm{b}]}$ (all data) & 0.1263 & 0.2515 & 0.1073 & 0.0883 & 0.1308 & 0.0709 \\
\hline Flack parameter & - & $0.50(7)$ & - & - & - & - \\
\hline $\operatorname{Max} / \min \Delta \rho / \mathrm{e} \cdot \AA^{-3}$ & $0.713 /-0.902$ & $1.287 /-1.633$ & $0.651 /-0.730$ & $0.464 /-0.243$ & $1.030 /-1.515$ & $1.488 /-0.310$ \\
\hline
\end{tabular}

${ }^{[\mathrm{a}]} R_{1}=\sum\left|F_{0}\right|-\left|F_{\mathrm{c}}\right|\left|/ \sum\right| F_{0} \mid .{ }^{[\mathrm{b}]} w R_{2}=\left[\sum \omega\left(F_{0}{ }^{2}-F_{\mathrm{c}}{ }^{2}\right)^{2}\right] /\left[\sum\left(\mathrm{F}_{0}{ }^{2}\right)^{2}\right]^{1 / 2}$. 


\section{Experimental Section}

General remarks: All manipulations are performed under an atmosphere of dry argon using standard glovebox and Schlenck techniques. Solvents are purified and degassed by standard procedures. NMR spectra are recorded on either a Bruker AMX 300 or Bruker Avance 400 spectrometer with $\delta$ referenced to external $\mathrm{SiMe}_{4}\left({ }^{1} \mathrm{H},{ }^{13} \mathrm{C}\right), \mathrm{H}_{3} \mathrm{PO}_{4}\left({ }^{31} \mathrm{P}\right)$, or $\mathrm{SnMe}_{4}\left({ }^{119} \mathrm{Sn}\right)$. The substances $\mathrm{LiP}\left(\mathrm{SiMe}_{3}\right)_{2} \cdot 1.8 \mathrm{THF},{ }^{[46]} \mathrm{Ph}^{*} \mathrm{I}^{[47]} \mathrm{Ph}^{*} \mathrm{Li} \cdot \mathrm{OEt}_{2},{ }^{[47]} \mathrm{Ph}^{*} \mathrm{GeCl},{ }^{[48]}$ and $\mathrm{Ph}^{*} \mathrm{SnCl}$ ${ }^{[49]}$ are prepared according to literature methods. Due to the sensibility of the compounds and, in some cases, the lack of material no elemental analyses of 2-10 could be performed. However, in most cases the MS analyses report the composition of the products.

Synthesis of $\mathbf{P h} * \mathrm{SnCl}_{\mathbf{3}}$ (1a): $\operatorname{Method~A}: \mathrm{SnCl}_{4}(0.90 \mathrm{~mL}, 2.0 \mathrm{~g}, 7.7 \mathrm{mmol})$ was dissolved in 5 $\mathrm{mL} n$-hexane. $5 \mathrm{~mL} \mathrm{Et}_{2} \mathrm{O}$ was added, and the resulting white suspension was cooled to $-78^{\circ} \mathrm{C}$. A solution of $\mathrm{Ph} * \mathrm{Li}^{-} \mathrm{OEt}_{2}(4.319 \mathrm{~g}, 7.7 \mathrm{mmol})$ in $50 \mathrm{~mL} \mathrm{Et}{ }_{2} \mathrm{O}$ was then added dropwise. The reaction mixture was slowly allowed to warm to room temperature and stirred overnight. The solvent was removed in vacuo, and the white residue was extracted with $40 \mathrm{~mL} n$-hexane. Upon filtration through Kieselgur, the filtrate was concentrated under reduced pressure to about $15 \mathrm{~mL}$ and stored at $-25^{\circ} \mathrm{C}$, whereby colorless microcrystals of $1 \mathrm{a}$ precipitate overnight. The mother liquor was decanted, and the crystals were dried under vacuum $(2.01 \mathrm{~g}$, $37 \%)$.

Method B: $\mathrm{PCl}_{3}(45 \mu \mathrm{L}, 72 \mathrm{mg}, 0.52 \mathrm{mmol})$ was added by pipette to a solution of $\mathrm{Ph} * \mathrm{SnCl}(\mathbf{5})$ (333 mg, $0.52 \mathrm{mmol})$ in $n$-hexane $(20 \mathrm{~mL})$ at $-78^{\circ} \mathrm{C}$. The solution turned immediately from orange to colorless. The solution was allowed to warm to room temperature and stirred overnight, after which a colorless solution with yellow precipitate (probably $(\mathrm{PCl})_{\mathrm{n}}$ ) was observed. The solution was filtered through a plug of Kieselgur, and the filtrate was concentrated to $5 \mathrm{~mL}$ under vacuum. Storage at $-25^{\circ} \mathrm{C}$ for five days afforded colorless crystals of $1 \mathbf{a}(249 \mathrm{mg}, 68 \%)$.

1a: MS (EI, $\left.70 \mathrm{eV}, 160^{\circ} \mathrm{C}\right): \mathrm{m} / z=706.2\left(\mathrm{M}^{+}, 13 \%\right), 671.2\left(\mathrm{M}^{+}-\mathrm{Cl}, 4 \%\right), 481.4\left(\mathrm{M}^{+}-\mathrm{SnCl}_{3}\right.$, 99\%), $466.3\left(\mathrm{M}^{+}-\mathrm{SnCl}_{3}-\mathrm{CH}_{3}, 34 \%\right), 438.4\left(\mathrm{M}^{+}-\mathrm{SnCl}_{3}-\mathrm{C}_{3} \mathrm{H}_{7}, 14 \%\right)$. Element. Analysis: $\mathrm{C}_{36} \mathrm{H}_{49} \mathrm{SnCl}_{3}\left(706.2 \mathrm{~g} / \mathrm{mol}\right.$ ): C 62.10 (calc. 61.20); H 6.41 (6.99)\%. ${ }^{1} \mathbf{H}$ NMR $\left(\mathrm{C}_{6} \mathrm{D}_{6}, 25^{\circ} \mathrm{C}\right)$ : $\delta=1.04\left(\mathrm{~d},{ }^{3} J_{\mathrm{HH}}=6.9 \mathrm{~Hz}, 12 \mathrm{H}, o-\mathrm{CH}\left(\mathrm{CH}_{3}\right)_{2}\right), 1.23\left(\mathrm{~d},{ }^{3} J_{\mathrm{HH}}=6.9 \mathrm{~Hz}, 12 \mathrm{H}, o-\mathrm{CH}\left(\mathrm{CH}_{3}\right)_{2}\right)$, $1.44\left(\mathrm{~d},{ }^{3} J_{\mathrm{HH}}=6.9 \mathrm{~Hz}, 12 \mathrm{H}, p-\mathrm{CH}\left(\mathrm{CH}_{3}\right)_{2}\right), 2.82\left(\mathrm{~m}, \mathrm{CH}\left(\mathrm{CH}_{3}\right)_{2}\right), 7.07\left(\mathrm{t},{ }^{3} J_{\mathrm{HH}}=7.7 \mathrm{~Hz}, 1 \mathrm{H}\right.$, $p-\mathrm{C}_{6} \mathrm{H}_{3}$ ), 7.22 (s, $4 \mathrm{H}, m$-Trip), 7.24 (br, $\left.2 \mathrm{H}, m-\mathrm{C}_{6} \mathrm{H}_{3}\right) .{ }^{13} \mathbf{C} \mathbf{N M R}\left(75.47 \mathrm{MHz}, \mathrm{C}_{6} \mathrm{D}_{6}\right): \delta=$ $23.01\left(\mathrm{~s}, \mathrm{CH}\left(\mathrm{CH}_{3}\right)_{2}\right), 24.12$ (s, $\left.\mathrm{CH}\left(\mathrm{CH}_{3}\right)_{2}\right), 26.04\left(\mathrm{~s}, \mathrm{CH}\left(\mathrm{CH}_{3}\right)_{2}\right), 31.41\left(\mathrm{~s}, \mathrm{CH}\left(\mathrm{CH}_{3}\right)_{2}\right), 34.96$ 
(s, $\left.\mathrm{CH}\left(\mathrm{CH}_{3}\right)_{2}\right), 122.07$ (s), 131.11 (s), 131.63 (s), 134.77 (s), 141.50 (s), 147.66 (s), 147.97 (s), 151.18 (s). ${ }^{119} \operatorname{Sn}\left\{{ }^{1} \mathbf{H}\right\}$ NMR (149.21 MHz, $\left.\mathrm{C}_{6} \mathrm{D}_{6}\right): \delta=-113.8$ (s).

Synthesis of $\mathbf{P h}^{*} \operatorname{SnBr}_{3}$ (1b): $\mathrm{Ph}^{*} \operatorname{SnBr}_{3}$ (1b) was prepared in the same manner as for $\mathbf{1 a}$ (Method A) starting from $\mathrm{SnBr}_{4}\left(326 \mathrm{mg}, 0.74 \mathrm{mmol}\right.$ ) and $\mathrm{Ph} * \mathrm{Li} \cdot \mathrm{OEt}_{2}(418 \mathrm{mg}, 0.74 \mathrm{mmol}$ ) to give colorless crystals of $\mathbf{1 b}$ in two crops (248 $\mathrm{mg}, 40 \%$ ).

1b: MS (EI, $70 \mathrm{eV}): m / z=837.9\left(\mathrm{M}^{+}, 7 \%\right), 796.9\left(\mathrm{M}^{+}-\mathrm{C}_{3} \mathrm{H}_{7}, 3.5 \%\right), 759.0\left(\mathrm{M}^{+}-\mathrm{Br}, 19 \%\right)$, $481.4\left(\mathrm{M}^{+}-\mathrm{SnBr}_{3}, 100 \%\right), 466.3\left(\mathrm{M}^{+}-\mathrm{SnBr}_{3}-\mathrm{CH}_{3}, 16 \%\right), 43.0\left(\mathrm{C}_{3} \mathrm{H}_{7}^{+}, 14 \%\right)$. Element. Analysis: $\mathrm{C}_{36} \mathrm{H}_{49} \mathrm{SnBr}_{3}(837.9 \mathrm{~g} / \mathrm{mol})$ : C 53.11 (calc. 51.49); H 6.11 (5.88)\%. ${ }^{1} \mathbf{H}$ NMR $\left(\mathrm{C}_{6} \mathrm{D}_{6}, 25^{\circ} \mathrm{C}\right): \delta=1.04\left(\mathrm{~d},{ }^{3} J_{\mathrm{HH}}=6.6 \mathrm{~Hz}, 12 \mathrm{H}, o-\mathrm{CH}\left(\mathrm{CH}_{3}\right)_{2}\right), 1.23\left(\mathrm{~d},{ }^{3} J_{\mathrm{HH}}=6.6 \mathrm{~Hz}, 12 \mathrm{H}, o-\right.$ $\left.\mathrm{CH}\left(\mathrm{CH}_{3}\right)_{2}\right), 1.46\left(\mathrm{~d},{ }^{3} \mathrm{~J}_{\mathrm{HH}}=6.8 \mathrm{~Hz}, 12 \mathrm{H}, p-\mathrm{CH}\left(\mathrm{CH}_{3}\right)_{2}\right), 2.87\left(\mathrm{~m}, \mathrm{CH}\left(\mathrm{CH}_{3}\right)_{2}\right), 7.03\left(\mathrm{t},{ }^{3} J_{\mathrm{HH}}=\right.$ $\left.7.6 \mathrm{~Hz}, 1 \mathrm{H}, p-\mathrm{C}_{6} \mathrm{H}_{3}\right), 7.21$ (s, $4 \mathrm{H}, m$-Trip). ${ }^{13} \mathbf{C ~ N M R}\left(75.47 \mathrm{MHz}, \mathrm{C}_{6} \mathrm{D}_{6}\right.$ ): $\delta=23.39$ (s, $\left.\mathrm{CH}\left(\mathrm{CH}_{3}\right)_{2}\right), 24.16$ (s, $\left.\mathrm{CH}\left(\mathrm{CH}_{3}\right)_{2}\right), 26.11$ (s, $\left.\mathrm{CH}\left(\mathrm{CH}_{3}\right)_{2}\right), 31.40$ (s, $\left.\mathrm{CH}\left(\mathrm{CH}_{3}\right)_{2}\right), 34.97$ (s, $\left.\mathrm{CH}\left(\mathrm{CH}_{3}\right)_{2}\right), 122.15$ (s), 130.65 (s), 132.10 (s), 134.35 (s), 139.37 (s), 147.30 (s), 147.82 (s), 151.02 (s). ${ }^{119} \operatorname{Sn}\left\{{ }^{1} \mathbf{H}\right\}$ NMR (149.21 MHz, $\left.\mathrm{C}_{6} \mathrm{D}_{6}\right): \delta=-332.6(\mathrm{~s})$.

Synthesis of $\mathbf{P h} * \mathbf{G e C l}_{\mathbf{3}}$ (2): $\mathrm{GeCl}_{4}(0.67 \mathrm{~mL}, 1.265 \mathrm{~g}, 5.9 \mathrm{mmol})$ was dissolved $10 \mathrm{~mL} \mathrm{Et}_{2} \mathrm{O}$. A solution of $\mathrm{Ph}^{*} \mathrm{Li}^{-} \mathrm{OEt}_{2}(3.318 \mathrm{~g}, 5.9 \mathrm{mmol})$ in $50 \mathrm{~mL} \mathrm{Et}_{2} \mathrm{O}$ was then added dropwise at $78^{\circ} \mathrm{C}$. The solution was slowly allowed to warm to room temperature and was stirred overnight. The solvent was removed under reduced pressure, and the white residue extracted with $40 \mathrm{~mL} n$-hexane. Upon filtration through Kieselgur, the filtrate was concentrated under vacuum until the onset of cristallization. Storage at $-25^{\circ} \mathrm{C}$ for five days afforded colorless crystals of 2 . The mother liquor was decanted, and the crystals were dried under vacuum $(1.752 \mathrm{~g}, 45 \%)$.

2: MS (EI, $70 \mathrm{eV}): m / z=660\left(\mathrm{M}^{+}, 26 \%\right), 645\left(\mathrm{M}^{+}-\mathrm{CH}_{3}, 3 \%\right), 481\left(\mathrm{M}^{+}-\mathrm{GeCl}_{3}, 71 \%\right), 466$ $\left(\mathrm{M}^{+}-\mathrm{GeCl}_{3}-\mathrm{CH}_{3}, 22 \%\right) .{ }^{1} \mathbf{H}$ NMR $\left(300 \mathrm{MHz}, \mathrm{C}_{6} \mathrm{D}_{6}, 25^{\circ} \mathrm{C}\right): \delta=1.24\left(\mathrm{~d},{ }^{3} J_{\mathrm{HH}}=6.9 \mathrm{~Hz}, 12\right.$ $\left.\mathrm{H}, p-\mathrm{CH}\left(\mathrm{CH}_{3}\right)_{2}\right), 1.29\left(\mathrm{~d},{ }^{3} J_{\mathrm{HH}}=6.9 \mathrm{~Hz}, 12 \mathrm{H}, o-\mathrm{CH}\left(\mathrm{CH}_{3}\right)_{2}\right), 1.32\left(\mathrm{~d},{ }^{3} J_{\mathrm{HH}}=6.9 \mathrm{~Hz}, 12 \mathrm{H}, o-\right.$ $\left.\mathrm{CH}\left(\mathrm{CH}_{3}\right)_{2}\right), 2.89\left(\mathrm{sept},{ }^{3} J_{\mathrm{HH}}=6.9 \mathrm{~Hz}, 2 \mathrm{H}, p-\mathrm{CH}\left(\mathrm{CH}_{3}\right)_{2}\right), 3.56\left(\mathrm{sept},{ }^{3} J_{\mathrm{HH}}=6.9 \mathrm{~Hz}, 4 \mathrm{H}, o-\right.$ $\left.\mathrm{CH}\left(\mathrm{CH}_{3}\right)_{2}\right), 7.05$ (s, $4 \mathrm{H}, m$-Trip), $7.31\left(\mathrm{~d},{ }^{3} J_{\mathrm{HH}}=6.9 \mathrm{~Hz}, 2 \mathrm{H}, m\right.$-Phenyl), $7.39\left(\mathrm{t},{ }^{3} J_{\mathrm{HH}}=6.9\right.$ $\mathrm{Hz}, 1 \mathrm{H}, p$-Phenyl).

Synthesis of $\mathbf{P h} * \operatorname{SnP}\left(\operatorname{SiMe}_{3}\right)_{2}$ (3): $\underline{\operatorname{Method} A}$ : A solution of $\mathrm{Ph}^{*} \operatorname{SnCl}_{3}$ (1a) (1.452 g, 2.06 $\mathrm{mmol})$ in $40 \mathrm{~mL} \mathrm{Et}{ }_{2} \mathrm{O}$ was cooled to $-78^{\circ} \mathrm{C}$. $\mathrm{LiP}\left(\mathrm{SiMe}_{3}\right)_{2} \cdot 1.8 \mathrm{THF}(677 \mathrm{mg}, 2.06 \mathrm{mmol})$ was 
added as a solid, and the solution slowly turned violet. The solution was allowed to stir overnight at room temperature, and then filtered through Kieselgur. A 5-mL aliquot of the filtrate was taken for ${ }^{31} \mathrm{P}$ NMR analysis, while the rest was concentrated to ca. $5 \mathrm{~mL}$ under reduced pressure and was stored at $-25^{\circ} \mathrm{C}$ for one week, after which colorless crystals of $\mathbf{3}$ deposited (750 mg, 46\%).

Method B: $\mathrm{Ph} * \mathrm{SnCl}(1.356 \mathrm{~g}, 2.1 \mathrm{mmol})$ was dissolved in $20 \mathrm{~mL} n$-hexane and cooled to $78^{\circ} \mathrm{C} . \mathrm{KP}\left(\mathrm{SiMe}_{3}\right)_{2}(465 \mathrm{mg}, 2.1 \mathrm{mmol})$ was added as a solid. Upon warming to room temperature, the color changed from orange to deep violet. The solution was stirred overnight and filtered through Kieselgur. The filtrate was concentrated to about $5 \mathrm{~mL}$ under vacuum and stored at $-25^{\circ} \mathrm{C}$, whereby violet crystals of $\mathbf{3}$ deposited after one week (799 $\mathrm{mg}, 49 \%$ ). 3 can also be synthesized from 5 and $\operatorname{LiP}\left(\mathrm{SiMe}_{3}\right)_{2} \cdot 1.8 \mathrm{THF}$ by an analogous procedure in approximately the same yield.

3: $\mathbf{M S}\left(\mathrm{EI}, 70 \mathrm{eV}, 120^{\circ} \mathrm{C}\right): \mathrm{m} / z=778.2\left(\mathrm{M}^{+}, 2.2 \%\right), 763.2\left(\mathrm{M}^{+}-\mathrm{CH}_{3}, 0.3 \%\right), 705.1\left(\mathrm{M}^{+}-\right.$ $\left.\mathrm{SiMe}_{3}, 0.3 \%\right), 690.2\left(\mathrm{M}^{+}-\mathrm{SiMe}_{3}-\mathrm{CH}_{3}, 1.5 \%\right), 675.3\left(\mathrm{M}^{+}-\mathrm{SiMe}_{3}-2 \mathrm{CH}_{3}, 1.6 \%\right), 601.1$ $\left(\mathrm{M}^{+}-\mathrm{P}\left(\mathrm{SiMe}_{3}\right)_{2}, 70 \%\right), 482.4\left(\mathrm{M}^{+}-\mathrm{SnP}\left(\mathrm{SiMe}_{3}\right)_{2}, 100 \%\right), 467.3\left(\mathrm{M}^{+}-\mathrm{SnP}\left(\mathrm{SiMe}_{3}\right)_{2}-\mathrm{CH}_{3}\right.$, 47\%), $439.3\left(\mathrm{M}^{+}-\mathrm{SnP}\left(\mathrm{SiMe}_{3}\right)_{2}-\mathrm{C}_{3} \mathrm{H}_{7}, 14 \%\right), 73\left(\mathrm{SiMe}_{3}{ }^{+}, 4 \%\right), 43.1\left(\mathrm{C}_{3} \mathrm{H}_{7}{ }^{+} 3 \%\right) .{ }^{1} \mathbf{H} \mathbf{~ N M R}$ $\left(\mathrm{C}_{6} \mathrm{D}_{6}, 25^{\circ} \mathrm{C}\right): \delta=0.16\left(\mathrm{~d},{ }^{3} J_{\mathrm{HP}}=4.0 \mathrm{~Hz}, 18 \mathrm{H}, \mathrm{Si}\left(\mathrm{CH}_{3}\right)_{3}\right), 1.13\left(\mathrm{~d},{ }^{3} J_{\mathrm{HH}}=6.7 \mathrm{~Hz}, 12 \mathrm{H}, o-\right.$ $\left.\mathrm{CH}\left(\mathrm{CH}_{3}\right)_{2}\right), 1.23\left(\mathrm{~d},{ }^{3} J_{\mathrm{HH}}=6.9 \mathrm{~Hz}, 12 \mathrm{H}, o-\mathrm{CH}\left(\mathrm{CH}_{3}\right)_{2}\right), 1.46\left(\mathrm{~d},{ }^{3} J_{\mathrm{HH}}=6.7 \mathrm{~Hz}, 12 \mathrm{H}, p-\right.$ $\left.\mathrm{CH}\left(\mathrm{CH}_{3}\right)_{2}\right), 2.79\left(\mathrm{sept},{ }^{3} J_{\mathrm{HH}}=6.9 \mathrm{~Hz}, 2 \mathrm{H}, p-\mathrm{CH}\left(\mathrm{CH}_{3}\right)_{2}\right), 3.28\left(\mathrm{sept},{ }^{3} J_{\mathrm{HH}}=6.8 \mathrm{~Hz}, 4 \mathrm{H}, o-\right.$ $\left.\mathrm{CH}\left(\mathrm{CH}_{3}\right)_{2}\right), 7.14$ (s, $4 \mathrm{H}, m$-Trip). ${ }^{13} \mathrm{C}$ NMR $\left(62.90 \mathrm{MHz}, \mathrm{C}_{6} \mathrm{D}_{6}\right): \delta=6.50\left(\mathrm{~d},{ }^{2} J_{\mathrm{CP}}=9.5 \mathrm{~Hz}\right)$, $24.25\left(\mathrm{~s}, \mathrm{CH}\left(\mathrm{CH}_{3}\right)_{2}\right), 25.09$ (s, $\left.\mathrm{CH}\left(\mathrm{CH}_{3}\right)_{2}\right), 27.95\left(\mathrm{~s}, \mathrm{CH}\left(\mathrm{CH}_{3}\right)_{2}\right), 32.01\left(\mathrm{~s}, \mathrm{CH}\left(\mathrm{CH}_{3}\right)_{2}\right), 35.54$ (s, $\left.\mathrm{CH}\left(\mathrm{CH}_{3}\right)_{2}\right), 122.81$ (s), 127.73 (s), 131.90 (s), 136.10 (s), 146.28 (s), 147.69 (s), 150.10 (s), 181.31 (s, ipso- $\left.\mathrm{C}_{6} \mathrm{H}_{3}\right) .{ }^{29} \mathbf{S i}\left\{{ }^{1} \mathbf{H}\right\}$ NMR $\left(49.69 \mathrm{MHz}, \mathrm{C}_{6} \mathrm{D}_{6}\right): \delta=4.08\left(\mathrm{~d},{ }^{1} J_{\mathrm{SiP}}=38.5 \mathrm{~Hz}\right)$. ${ }^{29} \mathrm{Si}$ NMR $\left(49.69 \mathrm{MHz}, \mathrm{C}_{6} \mathrm{D}_{6}\right): \delta=4.08\left(\mathrm{dm},{ }^{1} J_{\mathrm{SiP}}=38.5 \mathrm{~Hz},{ }^{2} J_{\mathrm{SiH}}=6.6 \mathrm{~Hz}\right) .{ }^{31} \mathbf{P} \mathbf{~ N M R}$ $\left(101.36 \mathrm{MHz}, \mathrm{C}_{6} \mathrm{D}_{6}\right): \delta=-123.1\left(\mathrm{~s},{ }^{1} J_{\mathrm{P} 117 \mathrm{Sn}}=1396 \mathrm{~Hz},{ }^{1} J_{\mathrm{P} 119 \mathrm{Sn}}=1453 \mathrm{~Hz}\right.$, total Sn satellite intensity $=12 \%) .{ }^{119}$ Sn NMR $\left(112.02 \mathrm{MHz}, \mathrm{C}_{6} \mathrm{D}_{6}\right): \delta=1919\left(\mathrm{~d},{ }^{1} J_{\mathrm{SnP}}=1453 \mathrm{~Hz}\right)$.

Synthesis of $\mathbf{P h} * \mathbf{G e P}\left(\mathrm{SiMe}_{3}\right)_{2}$ (4): $\underline{\operatorname{Method} A}$ : A solution of $\mathrm{LiP}\left(\mathrm{SiMe}_{3}\right)_{2}(499 \mathrm{mg}, 1.52$ mmol) in $20 \mathrm{~mL} \mathrm{Et}_{2} \mathrm{O}$ was added dropwise to a solution of $\mathrm{Ph}^{*} \mathrm{GeCl}_{3}$ (2) (1 g, $\left.1.52 \mathrm{mmol}\right)$ in $40 \mathrm{~mL} \mathrm{Et}_{2} \mathrm{O}$ at $-78^{\circ} \mathrm{C}$. Upon warming to room temperature, the color changed from orange to deep red. The solution was allowed to warm to room temperature and was stirred for $16 \mathrm{~h}$. After filtration through Kieselgur the filtrate was concentrated under vacuum to about $5 \mathrm{~mL}$ and stored at $-25^{\circ} \mathrm{C}$, whereby red crystals of $\mathbf{4}$ deposited after two weeks (70 $\mathrm{mg}, 7 \%$ ). 
Method B: $\mathrm{Ph} * \mathrm{GeCl}(897 \mathrm{mg}, 1.52 \mathrm{mmol})$ was dissolved in $40 \mathrm{~mL} \mathrm{Et}_{2} \mathrm{O}$ and cooled to $-78^{\circ} \mathrm{C}$. A solution of $\mathrm{LiP}\left(\mathrm{SiMe}_{3}\right)_{2}(499 \mathrm{mg}, 1.52 \mathrm{mmol})$ in $20 \mathrm{~mL} \mathrm{Et}_{2} \mathrm{O}$ was added dropwise . Upon warming to room temperature, the color changed from orange to deep red. The solution was stirred overnight and filtered through Kieselgur. Red crystals of $\mathrm{Ph} * \mathrm{GeP}\left(\mathrm{SiMe}_{3}\right)_{2}$ (4) were obtained in similar yield as for method A.

4: MS (EI, $70 \mathrm{eV}): m / z=733\left(\mathrm{M}^{+}, 40 \%\right), 719\left(\mathrm{M}^{+}-\mathrm{CH}_{3}, 4 \%\right), 677\left(\mathrm{M}^{+}-{ }^{\mathrm{i}} \mathrm{Pr}, 13 \%\right) .{ }^{31} \mathbf{P}$ NMR (101.36 MHz, $\left.\mathrm{C}_{6} \mathrm{D}_{6}\right): \delta=-48.6(\mathrm{~s})$.

Synthesis of $\mathbf{P h} * \mathbf{S n P}(\mathbf{H})$ Trip (6): TripPH $\mathrm{H}_{2}(57 \mathrm{mg}, 0.24 \mathrm{mmol})$ was dissolved in $10 \mathrm{~mL} \mathrm{Et}_{2} \mathrm{O}$ and cooled to $-78^{\circ} \mathrm{C}$. A solution of $n \operatorname{BuLi}(0.15 \mathrm{~mL}, 1.6 \mathrm{M}$ in $n$-hexane, $0.24 \mathrm{mmol})$ was added slowly by pipette. The mixture was allowed to warm to room temperature and stirred for one hour. The resulting $\mathrm{LiP}(\mathrm{H})$ Trip solution was added dropwise to a solution of $\mathrm{Ph} * \mathrm{SnCl}$ (5) $(154 \mathrm{mg}, 0.24 \mathrm{mmol})$ in $8 \mathrm{~mL} \mathrm{Et}_{2} \mathrm{O}$ and cooled to $-78^{\circ} \mathrm{C}$. The solution was allowed to warm slowly to room temperature, whereby the orange solution slowly became brown. After stirring overnight, the solution was filtered through Kieselgur and the solvent removed. The resulting brown residue was analyzed by ${ }^{31} \mathrm{P} \mathrm{NMR}$, which indicated formation of Trip $(\mathrm{H}) \mathrm{P}-$ P(H)Trip (ca. 20\%) and 6 (ca. 70\%) alongside unreacted TripPH $\mathrm{P}_{2}$ (ca. 10\%).

6: ${ }^{31} \mathbf{P}$ NMR $\left(162 \mathrm{MHz}, \mathrm{C}_{6} \mathrm{D}_{6}\right): \delta=-70.9\left(\mathrm{br}, \Delta v_{1 / 2}=150 \mathrm{~Hz},{ }^{1} J_{\mathrm{PH}}=186 \mathrm{~Hz},{ }^{1} J_{\mathrm{P} 117 / 1199 \mathrm{Sn}}=934\right.$ $\mathrm{Hz} ;{ }^{117 / 119} \mathrm{Sn}$ satellites could not be resolved, total Sn satellite intensity $=12 \%$ ).

Synthesis of $\mathrm{Li}^{+}\left[\mathrm{Ph}^{*}\right.$ SnPTrip] ${ }^{-}$(7, proposed): To a solution of TripPH $\mathrm{P}_{2}$ (64 $\mathrm{mg}, 0.27 \mathrm{mmol}$ ) in $10 \mathrm{~mL} \mathrm{Et}_{2} \mathrm{O}$ was added a solution of $n \mathrm{BuLi}(0.34 \mathrm{~mL}, 1.6 \mathrm{M}$ in $n$-hexane, $0.54 \mathrm{mmol})$ at $78^{\circ} \mathrm{C}$. The resulting solution was allowed to warm to room temperature and stirred for 3 hours. The yellow solution of $\mathrm{Li}_{2}$ PTrip was added slowly to a solution of $\mathrm{Ph} * \mathrm{SnCl}(\mathbf{5})$ (171 $\mathrm{mg}, 0.27 \mathrm{mmol})$ in $10 \mathrm{~mL} \mathrm{Et}_{2} \mathrm{O}$ at $-78^{\circ} \mathrm{C}$. The resulting solution was allowed to warm slowly to room temperature, whereby the orange color gradually became brown. After overnight stirring, the solution was filtered through Kieselgur and the solvent removed. The resulting brown residue was analyzed by ${ }^{31} \mathrm{P}$ NMR, whereby a mixture of signals indicated formation of Trip(H)P-P(H)Trip (ca. 20\%) and $\mathrm{Li}^{+}\left[\mathrm{Ph}^{*} \text { SnPTrip] }\right]^{-}$(7, proposed, ca. 40\%).

7: ${ }^{31} \mathbf{P}$ NMR $\left(162 \mathrm{MHz}, \mathrm{C}_{6} \mathrm{D}_{6}\right): \delta=229.7\left(\mathrm{br}, \Delta \mathrm{v}_{1 / 2}=280 \mathrm{~Hz},{ }^{1} J_{\mathrm{P} 117 \mathrm{Sn}}=1735 \mathrm{~Hz},{ }^{1} J_{\mathrm{P} 119 \mathrm{Sn}}=\right.$ $2004 \mathrm{~Hz}$, total Sn satellite intensity = ca. 14\%).

Synthesis of $\left[\mathbf{P h} * \mathbf{S n}\left\{\mathbf{W}(\mathbf{C O})_{5}\right\}(\mu-\mathbf{O})_{2} \mathbf{S n P h} *\right](8)$ : A solution of $\mathrm{Ph} * \mathrm{SnCl}(5)(198 \mathrm{mg}, 0.31$ $\mathrm{mmol}$ ) in $10 \mathrm{~mL} n$-hexane was added dropwise to a vigorously stirred suspension of 
$\mathrm{Li}\left[\mathrm{H}_{2} \mathrm{PW}(\mathrm{CO})_{5}\right](113 \mathrm{mg}, 0.31 \mathrm{mmol})$ in $5 \mathrm{~mL} n$-hexane at $-78^{\circ} \mathrm{C}$. The resulting pale redbrown suspension was allowed to warm to room temperature and stirred overnight. The solution was filtered through Kieselgur, and the volume was reduced under vacuum to $1 \mathrm{~mL}$. Storage at $-25^{\circ} \mathrm{C}$ for several weeks yielded a mixture of colorless, yellow, and orange crystals, from which an orange crystal was selected for an X-ray diffraction experiment and determined crystallographically to be compound 8. Among the mixture of crystals the presence of $\left[\mathrm{H}_{3} \mathrm{PW}(\mathrm{CO})_{5}\right]$ was shown by EI mass spectrometry, but no other compounds could be unambiguously identified. The synthesis of $\mathbf{8}$ could not be reproduced, thus preventing preparative isolation and further spectroscopic characterization. The mass spectrometric data given below were measured for the actual crystal that was used in the Xray experiment.

8: MS (EI, $\left.70 \mathrm{eV}, 380^{\circ} \mathrm{C}\right): \mathrm{m} / \mathrm{z}=594.5\left(\left[\mathrm{Sn}_{2} \mathrm{O}_{2} \mathrm{~W}(\mathrm{CO})_{5}\right]^{+}, 11 \%\right), 566.5\left(\left[\mathrm{Sn}_{2} \mathrm{O}_{2} \mathrm{~W}(\mathrm{CO})_{4}\right]^{+}\right.$, $33 \%), 538.5\left(\left[\mathrm{Sn}_{2} \mathrm{O}_{2} \mathrm{~W}(\mathrm{CO})_{3}\right]^{+}, 38 \%\right), 510.5\left(\left[\mathrm{Sn}_{2} \mathrm{O}_{2} \mathrm{~W}(\mathrm{CO})_{2}\right]^{+}, 16 \%\right), 43.1\left(\left[\mathrm{C}_{3} \mathrm{H}_{7}\right]^{+}, 54 \%\right)$.

Synthesis of $\mathbf{P h}{ }^{*} \operatorname{Sn}\left(\mathrm{OSiMe}_{3}\right)_{2} \mathbf{C l}$ (9): Excess trimethylsilylperoxide $(0.2 \mathrm{~mL}$, ca. $200 \mathrm{mg}$, ca. $1.1 \mathrm{mmol})$ was added by pipette to a solution of $\mathrm{Ph} * \mathrm{SnCl}(5)(560 \mathrm{mg}, 0.88 \mathrm{mmol})$ in $10 \mathrm{~mL}$ $\mathrm{Et}_{2} \mathrm{O}$ at $0^{\circ} \mathrm{C}$. The color changed immediately from orange to colorless. The solution was allowed to warm to room temperature and stirred for one hour. After filtration through Kieselgur, the filtrate was concentrated under reduced pressure to $2 \mathrm{~mL}$ and stored at $-25^{\circ} \mathrm{C}$. Colorless crystals formed after one week, were separated from the mother liquor by decantation, and dried under vacuum (172 $\mathrm{mg}, 24 \%)$.

9: $\mathbf{M S}\left(\mathrm{EI}, 70 \mathrm{eV}, 120^{\circ} \mathrm{C}\right): \mathrm{m} / z=799.1\left(\mathrm{M}^{+}-\mathrm{CH}_{3}, 1 \%\right), 741.0\left(\mathrm{M}^{+}-\mathrm{SiMe}_{3}, 1.2 \%\right), 725.1$ $\left(\mathrm{M}^{+}-\mathrm{OSiMe}_{3}, 1.6 \%\right), 652.1\left(\mathrm{M}^{+}-\mathrm{OSiMe}_{3}-\mathrm{SiMe}_{3}, 1.3 \%\right), 636.1\left(\mathrm{M}^{+}-2 \mathrm{OSiMe}_{3}, 0.8 \%\right)$, $601.1\left(\mathrm{M}^{+}-2 \mathrm{OSiMe}_{3}-\mathrm{Cl}, 1.2 \%\right), 482.2\left(\mathrm{M}^{+}-\mathrm{Sn}\left(\mathrm{OSiMe}_{3}\right)_{2} \mathrm{Cl}, 100 \%\right), 467.2\left(\mathrm{M}^{+}-\right.$ $\left.\mathrm{Sn}\left(\mathrm{OSiMe}_{3}\right)_{2} \mathrm{Cl}-\mathrm{CH}_{3}, 100 \%\right), 439.1\left(\mathrm{M}^{+}-\mathrm{Sn}\left(\mathrm{OSiMe}_{3}\right)_{2} \mathrm{Cl}-\mathrm{C}_{3} \mathrm{H}_{7}, 46 \%\right), 424.2\left(\mathrm{M}^{+}-\right.$ $\left.\mathrm{Sn}\left(\mathrm{OSiMe}_{3}\right)_{2} \mathrm{Cl}-\mathrm{C}_{3} \mathrm{H}_{7}-\mathrm{CH}_{3}, 20 \%\right) .{ }^{1} \mathbf{H} \mathbf{N M R}\left(\mathrm{C}_{6} \mathrm{D}_{6}, 25^{\circ} \mathrm{C}\right): \delta=0.13\left(\mathrm{~d}, 18 \mathrm{H}, \mathrm{Si}\left(\mathrm{CH}_{3}\right)_{3}\right)$, $1.07\left(\mathrm{~d},{ }^{3} J_{\mathrm{HH}}=6.9 \mathrm{~Hz}, 12 \mathrm{H}, o-\mathrm{CH}\left(\mathrm{CH}_{3}\right)_{2}\right), 1.20\left(\mathrm{~d},{ }^{3} J_{\mathrm{HH}}=6.8 \mathrm{~Hz}, 12 \mathrm{H}, o-\mathrm{CH}\left(\mathrm{CH}_{3}\right)_{2}\right), 1.30$ $\left(\mathrm{d},{ }^{3} J_{\mathrm{HH}}=6.9 \mathrm{~Hz}, 12 \mathrm{H}, p-\mathrm{CH}\left(\mathrm{CH}_{3}\right)_{2}\right), 2.91\left(\mathrm{~m}, 6 \mathrm{H}, \mathrm{CH}\left(\mathrm{CH}_{3}\right)_{2}\right), 7.06\left(\mathrm{t},{ }^{3} J_{\mathrm{HH}}=7.5 \mathrm{~Hz}, 1 \mathrm{H}\right.$, $p$ - $\mathrm{C}_{6} \mathrm{H}_{3}$ ), 7.18 (s, $4 \mathrm{H}, m$ - Trip), 7.21 (br, $2 \mathrm{H}, m-\mathrm{C}_{6} \mathrm{H}_{3}$ ).

Synthesis of $[\mathbf{P h} * \mathbf{S n}(\mu-\mathbf{O}) \mathbf{C l}]_{\mathbf{2}}$ (10): Trimethylamine $N$-oxide (59 $\mathrm{mg}, 0.79 \mathrm{mmol}$ ) was added as a solid to a solution of $\mathrm{Ph} * \mathrm{SnCl}(500 \mathrm{mg}, 0.79 \mathrm{mmol})$ in $15 \mathrm{~mL} \mathrm{Et}_{2} \mathrm{O}$ at $0^{\circ} \mathrm{C}$. The color changed within 30 minutes from orange to colorless. The solution was allowed to warm to room temperature and stirred for two hours, after which the solution had become cloudy. $\mathrm{Et}_{2} \mathrm{O}$ 
was added by Teflon cannula until the solution became clear (ca. $15 \mathrm{~mL}$ ). After filtration through Kieselgur, the filtrate was concentrated under reduced pressure until the onset of crystallization and stored at $-25^{\circ} \mathrm{C}$. Colorless crystals formed after four days, were separated from the mother liquor by decantation, and dried under vacuum (216 mg, 42\%).

10: $\mathbf{I R}(\mathrm{KBr}): \tilde{v}=3053$ (m), 2860 (m), 1962 (w), 1760 (m), 1605 (s), 1564 (s), 1385 (s), 1362 (s), 1318 (s), 1251 (s), 1240 (s), 1188 (m), 1164 (vs), 1154 (m), 1100 (vs), 1080 (s), 1071 (s), 1055 (s), 916 (s), 875 (s), 805 (s), 776 (s), 750 (s), 654 (s), 497 (s) cm cm $^{-1}$ MS (FD, toluene solution): $m / z=1304.6\left(\mathrm{M}^{+}, 100 \%\right) .{ }^{1} \mathbf{H} \mathbf{~ N M R}\left(\mathrm{C}_{6} \mathrm{D}_{6}, 25^{\circ} \mathrm{C}\right): \delta=1.02\left(\mathrm{~d},{ }^{3} J_{\mathrm{HH}}=6.9 \mathrm{~Hz}, 12\right.$ $\left.\mathrm{H}, \mathrm{CH}\left(\mathrm{CH}_{3}\right)_{2}\right), 1.36\left(\mathrm{~d},{ }^{3} \mathrm{~J}_{\mathrm{HH}}=6.8 \mathrm{~Hz}, 12 \mathrm{H}, \mathrm{CH}\left(\mathrm{CH}_{3}\right)_{2}\right), 1.46\left(\mathrm{~d},{ }^{3} \mathrm{~J}_{\mathrm{HH}}=6.9 \mathrm{~Hz}, 12 \mathrm{H}\right.$, $\left.\mathrm{CH}\left(\mathrm{CH}_{3}\right)_{2}\right), 2.86\left(\mathrm{~m}, 6 \mathrm{H}, \mathrm{CH}\left(\mathrm{CH}_{3}\right)_{2}\right), 7.22$ (s, $4 \mathrm{H}, m$-Trip). ${ }^{13} \mathbf{C ~ N M R}\left(75.48 \mathrm{MHz}, \mathrm{C}_{6} \mathrm{D}_{6}\right): \delta$ $=23.45\left(\mathrm{~s}, \mathrm{CH}\left(\mathrm{CH}_{3}\right)_{2}\right), 24.20\left(\mathrm{~s}, \mathrm{CH}\left(\mathrm{CH}_{3}\right)_{2}\right), 26.17\left(\mathrm{~s}, \mathrm{CH}\left(\mathrm{CH}_{3}\right)_{2}\right), 31.34\left(\mathrm{~s}, \mathrm{CH}\left(\mathrm{CH}_{3}\right)_{2}\right), 34.75$ (s, $\left.\mathrm{CH}\left(\mathrm{CH}_{3}\right)_{2}\right), 121.64$ (s), 127.71 (s), 130.17 (s), 131.08 (s), 136.59 (s), 147.22 (s), 147.90 (s), $149.88(\mathrm{~s})$.

Crystal structure analysis: The crystal structure analyses were performed on an Oxford Diffraction Gemini R Ultra CCD $(\mathbf{2}, \mathbf{4})$ using $\mathrm{Cu}_{\mathrm{K} \alpha}$ radiation $(\lambda=1.54184 \AA$ $)$ and a STOE IPDS diffractometer $(\mathbf{1 a}, \mathbf{3}, \mathbf{8}, \mathbf{1 0})$ using $\mathrm{Mo}_{\mathrm{K \alpha}}$ radiation $(\lambda=0.71073 \AA)$, respectively. Semiempirical absorption corrections from equivalents (multi-scan) were applied for 2 and $\mathbf{4}^{[50]}$ For 1a, 3, 8 and 10 numerical absorption corrections from crystal faces were carried out. ${ }^{[51]}$ 1a, 3, 8 and 10 were solved by direct methods with the program SIR-97. ${ }^{[52]} \mathbf{2}$ could not be solved using direct methods or Patterson methods. Hence it was solved using charge-flipping algorithms from SUPERFLIP. ${ }^{[53]}$ Full matrix least-square refinement on $\mathrm{F}^{2}$ in SHELXL$97^{[54]}$ was performed with anisotropic displacements for non-H atoms. Hydrogen atoms were located in idealized positions and refined isotropically according to the riding model. In 8 and 10 iso-propyl groups are disordered over two positions. Thus several constraints and restraints have been used for refinement. Disordered hexane molecules in $\mathbf{8}$ and $\mathbf{1 0}$ could not be refined properly and were squeezed using the appropriate function in PLATON software. ${ }^{[55]}$ Additionally, 2 is an inversion twin (50:50) and a mixed crystal with 50 percent occupancy each site for $\mathrm{Ph} * \mathrm{GeCl}$ and $\mathrm{Ph}^{*} \mathrm{GeCl}_{3}$. Further all four chlorine- and iso-propyl positions are disordered over two positions. For this reasons constraints and restraints are required and Rvalues are poor for $\mathbf{2}$. Further details are given in table 1 .

CCDC-760737 (1a), -760738 (2), -760739 (3), -760740 (4), -760741 (8), and -760736 (10) contain the supplementary crystallographic data for this paper. These data can be obtained free of charge from the Cambridge Crystallographic Data Centre via 
www.ccdc.cam.ac.uk/conts/retrieving.html (or from the Cambridge Crystallographic Data Centre, 12 Union Road, Cambridge CB2 1EZ, UK (Fax: (+44)1223-336033; e-mail: deposit@ccdc.cam.ac.uk)).

DFT calculations: All calculations were performed using the Gaussian 03 program package. ${ }^{[36]}$ For structure optimisation we employed the functional theory (DFT) method along with the B3LYP exchange-correlation functional ${ }^{[56]}$ and SDD basis set (Stuttgart/Dresden pseudorelativistic effective core potential for $\mathrm{Sn}^{[57]}$ and D95 full double zeta basis sets for all other atoms ${ }^{[58]}$ ).

\section{Acknowledgments}

This work is comprehensively supported by the Deutsche Forschungsgemeinschaft and the Fonds der Chemischen Industrie. F. Dielmann thanks the Studienstiftung des Deutschen Volkes for a $\mathrm{PhD}$ fellowship.

\section{References}

[1] G. Becker, G. Gesser, W. Uhl, Z. Naturforsch. Teil B 1981, 36, 16.

[2] a) T. Allspach, M. Regitz, G. Becker, W. Becker, Synthesis 1986, 31; b) M. Regitz, P. Binger, Angew. Chem. 1988, 100, 1541; Angew. Chem. Int. Ed. 1988, 27, 1484; c) M. Regitz, Chem. Rev. 1990, 90, 191.

[3] Some examples: a) A. M. Arif, A. Barron, A. H. Cowley, S. W. Hall, J. Chem. Soc., Chem. Commun. 1988, 171; b) G. Becker, M. Bohringer, R. Gleiter, K.-H. Pfeifer, J. Grobe, D. LeVan, M. Hegemann, Chem. Ber. 1994, 127, 1041; c) G. Becker, K. Hubler, Z. Anorg. Allg. Chem. 1994, 620, 405; d) G. Becker, W. Schwarz, N. Seidler, M. Westerhausen, Z. Anorg. Allg. Chem. 1992, 612, 72.

[4] G. Märkl, H. Sejpka, Angew. Chem. 1986, 98, 286; Angew. Chem. Int. Ed. 1986, $25,264$.

[5] M. Finze, E. Bernhardt, H. Willner, C. W. Lehmann, Angew. Chem. 2004, 116, 4254; Angew. Chem. Int. Ed. 2004, 43, 4160 .

[6] a) M. Regitz, P. Binger, Angew. Chem. 1988, 100, 1541; Angew. Chem. Int. Ed. Engl. 1988, 27, 1484; b) M. Regitz, P. Binger in Multiple Bonds and Low Coordination in Phosphorus Chemistry (Hrsg.: M. Regitz, O. J. Scherer), Thieme, Stuttgart, 1990, p. 58; c) M. Regitz, Chem. Rev. 1990, 90, 191; d) A. Mack, M. Regitz, Chem. Ber. 1997, 130, 823; e) T. W. Mackewitz, M. Regitz, Synthesis 1998, 125; for synthesis of different phosphaalkynes cf.: J.-C. Guillemin, T. Janati, J.-M. Denis, J. Org. Chem. 2001, 66, 7864; for short living phosphaalkynes: A. C. Gaumont, J.-M. Denis, Chem. Rev. 1994, 94, 1413.

[7] a) J. F. Nixon, Chem. Rev. 1988, 88, 1327; b) P. Binger in Multiple Bonds and Low Coordination in Phosphorus Chemistry (Hrsg.: M. Regitz, O. J. Scherer), Thieme, Stuttgart, 1990, p. 90; c) J. F. Nixon, Chem. Ind. 1993, 404; d) J. F. Nixon, Coord. Chem. Rev. 1995, 145, 201; e) J. F. Nixon, Chem. Soc. Rev. 1995, 319; f) K. B. Dillon, F. Mathey, J. F. Nixon in Phosphorus, The Carbon Copy, Wiley, Chichester, 1998, pp 40; g) F. Mathey, Angew. Chem. 2003, 115, 1616; Angew. Chem. Int. Ed. 2003, 42, 1578. 
[8] a) P. P. Power, J. Chem. Soc., Dalton Trans. 1998, 18, 2939; b) P. P. Power, Chem. Rev. 1999, $99,3463$.

[9] a) C. N. Smit, F. M. Lock, F. Bickelhaupt, Tetrahedron Lett. 1984, 25, 3011; b) C. N. Smit, F. Bickelhaupt, Organometallics 1987, 6, 1156; c) E. Niecke, E. Klein, M. Nieger, Angew. Chem. 1989, 101, 792, Angew. Chem. Int. Ed. 1989, 28, 751.

[10] a) J. Escudié, C. Couret, J. Satgé, M. Andrianarison, J. D. Andriamizaka, J. Am. Chem. Soc. 1985, 107, 3378; b) H. Ranaivonjatovo, J. Escudié, C. Couret, J. Satgé, M. Dräger, New. J. Chem. 1989, 13, 389; c) H. Ranaivonjatovo, J. Escudié, C. Couret, J. Satgé, J. Organomet. Chem. 1991, 415, 327.

[11] a) C. Couret, J. Escudié, J. Satgé, A. Raharinirina, J. D. Andriamizaka, J. Am. Chem. Soc. 1985, 107, 8280; b) H. Ranaivonjatovo, J. Escudié, C. Couret, J. Satgé, J. Chem. Soc., Chem. Commun. 1992, 1047.

[12] a) M. Driess, Angew. Chem. 1991, 103, 979, Angew. Chem. Int. Ed. 1991, 30, 1022; b) M. Driess, U. Winkler, W. Imhof, L. Zsolnai, G. Huttner, Chem. Ber. 1994, 127, 1031.

[13] W. Setaka, K. Hirai, H. Tomioka, K. Sakamoto, M. Kira, J. Am. Chem. Soc. 2004, 126, 2696.

[14] B. Twamley, P. P. Power, J. Chem. Soc., Chem. Commun. 1998, 1979.

[15] R. C. Smith, P. Gantzel, A. L. Rheingold, J. D. Protasiewicz, J. Am. Chem. Soc. 2003, 125, 40.

[16] a) M. Scheer, K. Schuster, T. A. Budzichowski, M. H. Chisholm, W. E. Streib, J. Chem. Soc., Chem. Commun. 1995, 1671. b) P. Kramkowski, M. Scheer, G. Baum, J. Organomet. Chem. 1998, 553, 511; c) M. Scheer, J. Krug, Z. Anorg. Allg. Chem. 1998, 624, 399; d) T. Gröer, G. Baum, M. Scheer, Organometallics 1998, 17, 5916; e) M. Scheer, E. Leiner, P. Kramkowski, M. Schiffer, G. Baum, Chem. Eur. J., 1998, 4, 1917; f) P. Kramkowski, M. Scheer, Angew. Chem. 1999, 111, 3384; Angew. Chem. Int. Ed. 1999, 38, 3183; g) M. Scheer, P. Kramkowski, K. Schuster, Organometallics 1999, 18, 2874; h) P. Kramkowski, G. Baum, U. Radius, M. Kaupp, M. Scheer, Chem. Eur. J. 1999, 5, 2890; i) P. Kramkowski, M. Scheer, Angew. Chem. 2000, 112, 959; Angew. Chem. Int. Ed. 2000, 39, 928; j) M. Scheer, D. Himmel, B. P. Johnson, C. Kuntz, M. Schiffer, Angew. Chem. 2007, 119, 4045; Angew. Chem. Int. Ed. 2007, 46, 3971.

[17] A. S. Ionkin, W. J. Marshall, Organometallics 2003, 22, 4136.

[18] J. Glatthaar, G. Maier, Angew. Chem. 2004, 116, 1314-1317; Chem. Int. Ed. 2004, 43, 1294.

[19] M. Driess, S. Block, M. Brym, M. T. Gamer, Angew. Chem. 2006, 118, 2351.; Angew Chem. Int. Ed. 2006, 45, 2293.

[20] a) M. Bender, E. Niecke, M. Nieger, R. Pietschnig, Eur. J. Inorg. Chem. 2006, 380; b) R. Pietschnig, J. J. Tirreé, in Organosilicon Chemistry - From Molecules to Materials VI, Vol. 1 (Eds.: N. Auner, J. Weis), Wiley-VCH, 2005, pp. 222.

[21] Y.-H. Hu, M.-D. Su, Chem. Phys. Lett. 2003, 378, 289.

[22] M. Saito, H. Hashimoto, T. Tajima, M. Ikeda, J. Organomet. Chem. 2007, 692, 2729.

[23] Bond lengths and angles for $\mathbf{2}$ are not listed, because the molecular structure of $\mathbf{2}$ is disordered due to contamination of the product with the starting material $\mathrm{Ph} * \mathrm{GeCl}$.

[24] H. Schumann, R. Fischer, J. Organomet. Chem. 1975, 88, C13.

[25] a) M. Scheer, F. Uhlig, T. T. Nam, M. Dargatz, H.-D. Schädler, E. Herrmann, Z. Anorg. Allg. Chem. 1990, 585, 177; b) M. Scheer, St. Gremler, E. Herrmann, U. Grünhagen, M. Dargatz, E. Kleinpeter, Z. Anorg. Allg. Chem. 1991, 600, 203; c) M. Scheer, St. Gremler, E. Herrmann, P. G. Jones, J. Organomet. Chem. 1991, 414, 337; d) S. Gremler, M. Scheer, Z. Anorg. Allg. Chem. 1993, 619, 466; e) M. Scheer, S. 
Gremler, Z. Anorg. Allg. Chem. 1993, 619, 471. M. Scheer, St. Gremler, E. Herrmann, M. Dargatz, H.-D. Schädler, Z. Anorg. Allg. Chem. 1993, 619, 1047.

[26] B. E. Eichler, L. Pu, M. Stender, P. P. Power, Polyhedron 2001, $20,551$.

[27] a) W.-W. du Mont, H. Schumann, Angew. Chem. 1975, 87, 354; Angew. Chem. Int. Ed. Engl. 1975, 14, 368; b) W.-W. du Mont, M. Grenz, Chem. Ber., 1985, 118, 1045.

[28] K. Izod, J. Stewart, W. Clegg, R. W. Harrington, Organometallics, 2010, 29, 108.

[29] M. F. Lappert, P. P. Power, J. Chem. Soc. Dalton Trans. 1985, 51.

[30] M. F. Lappert, M. C. Misra, M. Onyszchuk, R. S. Rowe, P. P. Power, M. J. Slade, J. Organomet. Chem. 1987, 330, 31.

[31] P. B. Hitchcock, H. A. Jasim, M. F. Lappert, W.-P. Leung, A. K. Rai, R. E. Taylor, Polyhedron 1991, 10, 1203.

[32] B. Twamley, N. J. Hardman, P. P. Power, Acta Cryst. 2000, C56, E514.

[33] B. Twamley, P. P. Power, J. Chem. Soc., Chem. Commun. 1998, 1979.

[34] L. Pu, A. D. Phillips, A. F. Richards, M. Stender, R. S. Simons, M. M. Olmstead, P. P. Power, J. Am. Chem. Soc. 2003, 125, 11626.

[35] a) M. Driess, Chemie in unserer Zeit 1993, 27, 141; b) M. Yoshifuji, I. Shima, N. Inamoto, K. Hirotsu, T. Higuchi, J. Am. Chem. Soc. 1981, 103, 4587; c) A. H. Cowley, Polyhedron 1984, 3, 389; d) L. Weber, Coord. Chem. Rev. 1992, 92, 1839; e) N. C. Norman, Polyhedron 1993, 12, 2431; f) A. H. Cowley, J. G. Lasch, N. C. Norman, M. Pakulski, J. Am. Chem. Soc. 1983, 105, 5506; g) C. Couret, J. Escudie, Y. Madaule, H. Ranaivonjatovo, J.-G. Wolf, Tetrahedron Lett. 1983, 24, 2769; h) N. Tokitoh, Y. Arai, T. Sasamori, R. Okazaki, S. Nagase, H. Uekusa, Y. Ohashi, J. Am. Chem. Soc. 1998, 120, 443; i) N. Tokitoh, Y. Arai, R. Okazaki, S. Nagase, Science 1997, 277, 78.

[36] Gaussian 03, Revision B.01, M. J. Frisch, G. W. Trucks, H. B. Schlegel, G. E. Scuseria, M. A. Robb, J. R. Cheeseman, J. A. Montgomery, Jr., T. Vreven, K. N. Kudin, J. C. Burant, J. M. Millam, S. S. Iyengar, J. Tomasi, V. Barone, B. Mennucci, M. Cossi, G. Scalmani, N. Rega, G. A. Petersson, H. Nakatsuji, M. Hada, M. Ehara, K. Toyota, R. Fukuda, J. Hasegawa, M. Ishida, T. Nakajima, Y. Honda, O. Kitao, H. Nakai, M. Klene, X. Li, J. E. Knox, H. P. Hratchian, J. B. Cross, C. Adamo, J. Jaramillo, R. Gomperts, R. E. Stratmann, O. Yazyev, A. J. Austin, R. Cammi, C. Pomelli, J. W. Ochterski, P. Y. Ayala, K. Morokuma, G. A. Voth, P. Salvador, J. J. Dannenberg, V. G. Zakrzewski, S. Dapprich, A. D. Daniels, M. C. Strain, O. Farkas, D. K. Malick, A. D. Rabuck, K. Raghavachari, J. B. Foresman, J. V. Ortiz, Q. Cui, A. G. Baboul, S. Clifford, J. Cioslowski, B. B. Stefanov, G. Liu, A. Liashenko, P. Piskorz, I. Komaromi, R. L. Martin, D. J. Fox, T. Keith, M. A. Al-Laham, C. Y. Peng, A. Nanayakkara, M. Challacombe, P. M. W. Gill, B. Johnson, W. Chen, M. W. Wong, C. Gonzalez, J. A. Pople, Gaussian, Inc., Pittsburgh PA, 2003. For a current listing of basis sets and ECPs, see http://www.gaussian.com.

[37] a) D. Agustin, G. Rima, H. Gornitzka, J. Barrau, Eur. J. Inorg. Chem. 2000, 693; b) A. L. Balch, M. M. Olmstead, D. P. Oram, Inorg. Chem. 1988, 27, 4309; c) M. Weidenbruch, A. Stilter, J. Schläfke, K. Peters, H. G. von Schnering, J. Organomet. Chem. 1995, 501, 67; d) H.-P. Abicht, K. Jurkschat, A. Tzschach, K. Peters, E,-M. Peters, H. G. von Schnering, J. Organometal. Chem. 1987, 326, 357.

[38] J. Beckmann, K. Jurkschat, S. Rabe, M. Schürmann, Z. Anorg. Allg. Chem. 2001, 627, 2413.

[39] G. H. Spikes, Y. Peng, J. C. Fettinger, J. Steiner, P. P. Power, Chem. Commun. 2005, 6041. 
[40] For usage of $\mathrm{Me}_{3} \mathrm{SiOOSiMe}_{3}$ as a mild, non-radical oxidation agent, see: a) D. Brandes, A. Blaschette, J. Organomet. Chem. 1974, 73, 217; b) D. Brandes, A. Blaschette, J. Organomet. Chem. 1973, 49, C6; for similar oxidation of Sn(II) with benzoyl peroxide, see: c) A. Tzschach, M. Scheer, K. Jurkschat, Z. Anorg. Allg. Chem. 1984, 508, 73.

[41] L. Pu, N. J. Hardman, P. P. Power, Organometallics 2001, 20, 5105.

[42] M. A. Edelman, P. B. Hitchcock, M. F. Lappert, J. Chem. Soc., Chem. Commun. 1990, 1116.

[43] H. Puff, R. Gattermayer, R. Hundt, R. Zimmer, Angew. Chem. 1977, 89, 556; Angew. Chem. Int. Ed. 1977, 16, 547.

[44] P. Brown, M. F. Mahon, K. C. Molloy, J. Chem. Soc., Chem. Commun. 1989, 1621.

[45] J. Janssen, J. Magull, H. W. Roesky, Angew. Chem. 2002, 114, 1425; Angew. Chem. Int. Ed. 2002, 41, 1365.

[46] a) F. Uhlig, St. Gremler, M. Dargatz, M. Scheer, E. Herrmann, Z. Anorg. Allg. Chem. 1991, 606, 105; b) H. H. Karsch, F. Bienlein, T. Rupprich, F. Uhlig, E. Herrmann, M. Scheer, Synth. Methods Organomet. Inorg. Chem. 1996, 3, 58; c) G. Fritz, W. Hölderlin, Z. Anorg. Allg. Chem. 1976, 422, 104.

[47] B. Schiemenz, P. P. Power, Organometallics 1996, 15, 958.

[48] L. Pu, M. M. Olmstead, P. P. Power, B. Schiemenz, Organometallics 1998, 17, 5602.

[49] B. E. Eichler, L. Pu, M. Stender, P. P. Power, Polyhedron 2001, $20,551$.

[50] CrysAlis RED, Oxford Diffraction Ltd. Version 1.171.33.52, 2009.

[51] STOE (1998) IPDS-software, version 2.89, program FaceIt, STOE \& CIE GmbH, Darmstadt, Germany.

[52] A. Altomare, M. C. Burla, M. Camalli, G. L. Cascarano, C. Giacovazzo. A. Guagliardi, A. G. G. Moliterni, G. Polidori, R. Spagna, J. Appl. Cryst. 1999, 32, 115.

[53] L. Palatinus, G. Chapuis, J. Appl. Cryst. 2007, 40, 786.

[54] a) G. M. Sheldrick, SHELXL-97, University of Göttingen, 1997; b) G. M. Sheldrick, Acta Cryst. 2008, A64, 112 .

[55] A. L. Spek, J. Appl. Cryst. 2003, 36, 7.

[56] a) A. D. Becke, Phys. Rev. A 1988, 38, 3098; b) C. Lee, W. Yang, R. G. Parr, Phys. Rev. B 1988, 37, 785;

c) A. D. Becke, J. Chem. Phys. 1993, 98, 5648.

[57] A. Bergner, M. Dolg, H. Stoll, H. Preuss, Mol. Phys. 1993, 80, 1431,

[58] T. H. Dunning Jr., P. J. Hay, in Modern Theoretical Chemistry, Ed. H. F. Schaefer III, Vol. 3 (Plenum, New York, 1976) 1. 


1
2
3
4
5
6
7
8
9
10
11
12
13
14
15
16
17
18
19
20
21
22
23
24
25
26
27
28
29
30
31
32
33
34
35
36
37
38
39
40
41
42
43
44
45
46
47
48
49
50
51
52
53
54
55
56
57
58
59
60

Figure 1. Molecular structure of $\mathrm{Ph} * \mathrm{ECl} 3(1 \mathrm{a}: \mathrm{E}=\mathrm{Sn}, 2: \mathrm{E}=\mathrm{Ge}$ ) in the crystal. $\mathrm{H}$ atoms are omitted for clarity. Selected bond lengths $[\AA]$ and angles $\left[^{\circ}\right]$ for $1 \mathrm{a}$ : Sn-C1 2.155(5), Sn-Cl1 2.322(3), Sn$\mathrm{Cl} 2$ 2.321(3), Sn-Cl3 2.328(2); C1-Sn-Cl1 119.89(13), C1-Sn-Cl2 122.05(13), C1-Sn-Cl3 109.26(14), Cl1-Sn-Cl2 98.12(7), Cl1-Sn-Cl3 102.96(8), Cl2-Sn-Cl3 101.67(8). 
Figure 2. Molecular structures of $\mathrm{Ph} * \mathrm{EP}(\mathrm{SiMe}) 2(3: \mathrm{E}=\mathrm{Sn}, 4: \mathrm{E}=\mathrm{Ge})$ in the crystal. $\mathrm{H}$ atoms are omitted for clarity. Selected bond lengths $[\AA]$ and angles $\left[^{\circ}\right]$ for 3: C7-Sn 2.229(3), Sn-P 2.527(1), P-Si1 2.244(2), P-Si2 2.243(4); C7-Sn-P 105.61(8), Sn-P-Si1 97.40(5), Sn-P-Si2 110.02(5), Si1-P-Si2 110.58(6). Selected bond lengths [ $\AA$ ] and angles [ [ ${ }^{\circ}$ for 4: C7-Ge 2.018(5), Ge-P 2.291(4), P-Si1 2.240(5), P-Si2 2.248(1); C7-Ge-P 106.89(5), Ge-P-Si1 119.53(2), Ge-P-Si2 97.49(2), Si1-P-Si2 109.87(3). 

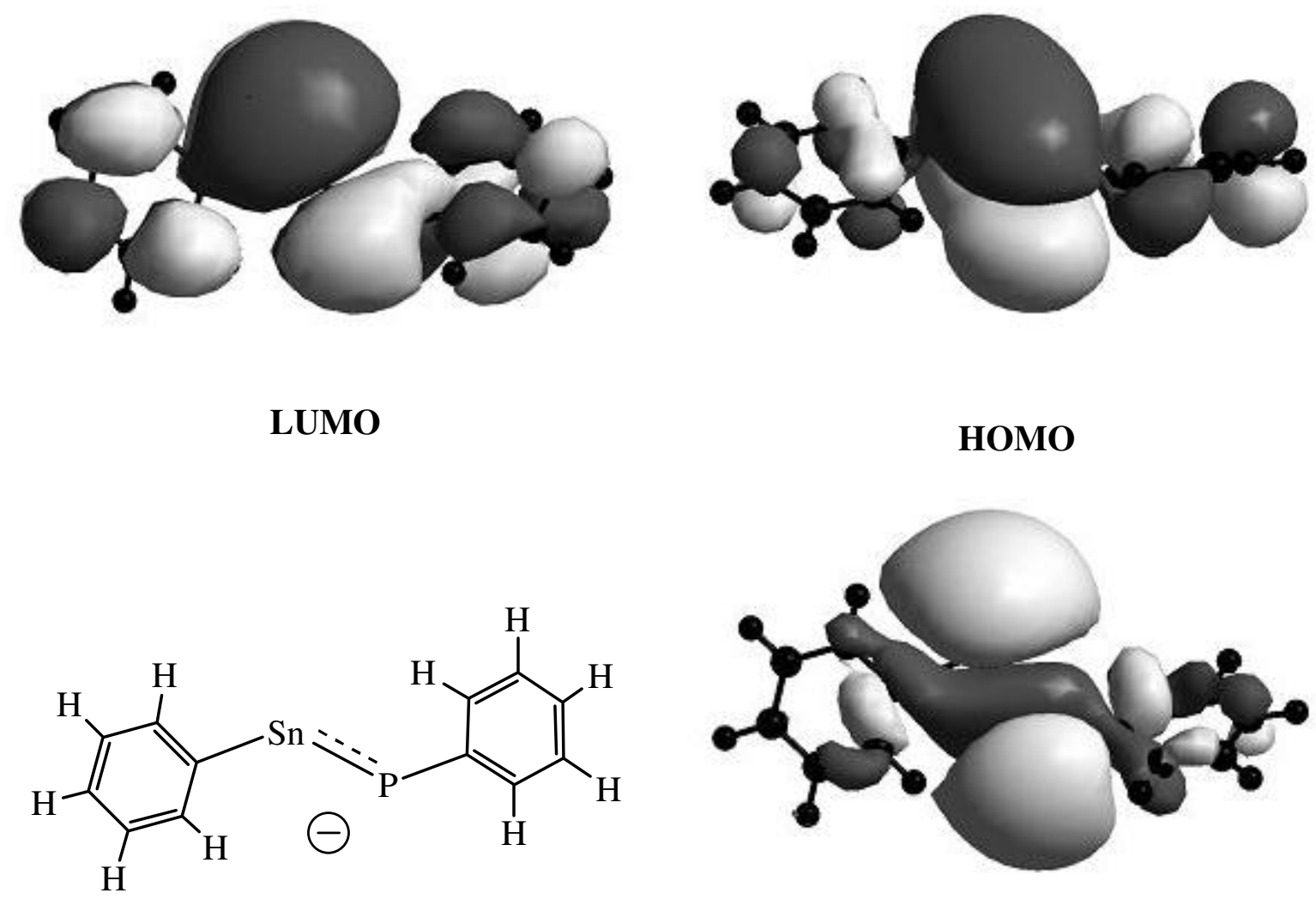

HOMO-1 


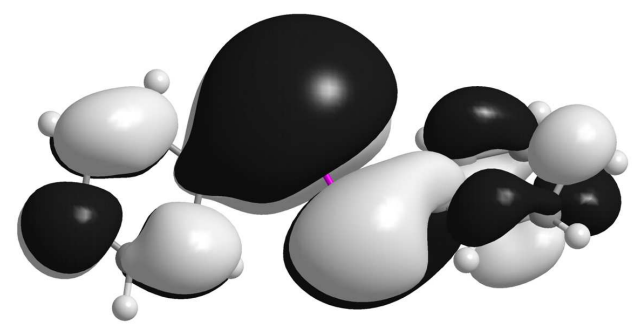

LUMO<smiles>c1ccccc1</smiles>

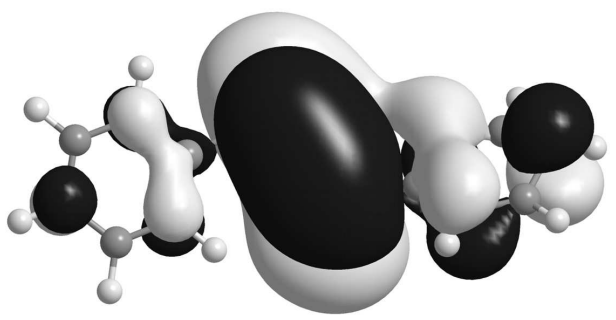

HOMO

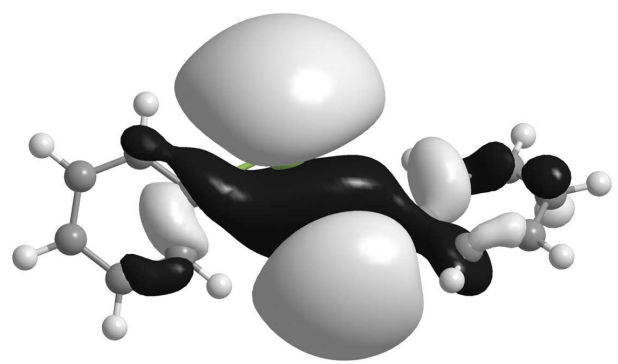

HOMO-1

Figure 3. Iso-surfaces of the molecular orbitals for model compound [PhSnPPh]- (7'). Upper left: LUMO; upper right: HOMO; lower left: graphical representation of anion considered; lower right: HOMO-1. $638 \times 422 \mathrm{~mm}(96 \times 96 \mathrm{DPI})$ 


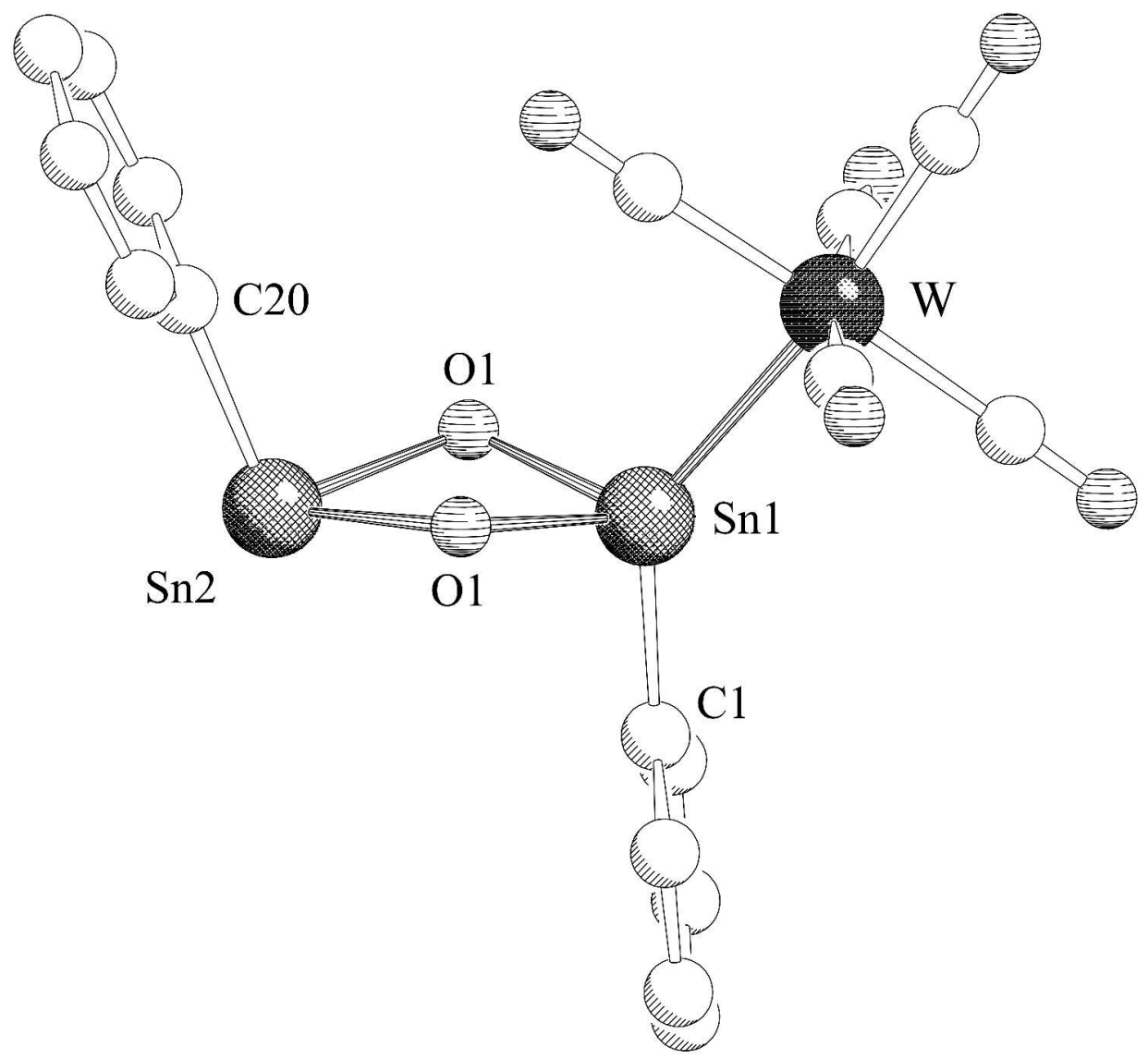

Figure 4. Molecular structure of $[\mathrm{Ph} * \mathrm{Sn}\{\mathrm{W}(\mathrm{CO}) 5\}(\mu-\mathrm{O}) 2 \mathrm{SnPh} *](8)$ in the crystal. The $\mathrm{H}$ atoms and o-Trip groups are omitted for clarity. Selected bond lengths $[\AA]$ and angles $\left[^{\circ}\right]$ : W1-Sn1 2.743(2), Sn1-C1 2.183(9), Sn2-C20 2.183(9), Sn1-O1 2.140(5), Sn2-O1 2.224(5), W1-Ctrans 1.978(15), W1-Ccis 2.058(14) (mean value is given); O1-Sn1-O1 73.0(3), O1-Sn2-O1 69.9(3), O1-Sn1-W1 111.57(14), Sn1-O1-Sn2 105.6(2), C1-Sn1-W1 137.9(3), C1-Sn1-01 101.9(3), C20-Sn2-O1 99.2(3). 
Figure 5. Molecular structure of $\left[\mathrm{Ph}^{*} \mathrm{Sn}(\mu-\mathrm{O}) \mathrm{Cl}\right] 2(10)$ in the crystal. $\mathrm{H}$ atoms are omitted for clarity. Selected bond lengths $[\AA]$ and angles [ $\left.{ }^{\circ}\right]$ : Sn1-O1 1.994(2), Sn1-Cl1 2.343(1), Sn1-Cipso 2.137(3); Sn1-O1-Sn1 95.38(9), O1-Sn1-O1 84.62(9), Cl1-Sn1-O1 108.47(6), Cl1-Sn1-O1 106.36(7), Cipso-Sn1-O1 117.28(10), Cipso-Sn1-O1 119.98(9), Cl1-Sn1-Cipso 115.76(8). 